\title{
Setting of $\mathrm{Zn}-\mathrm{Cu}-\mathrm{Au}-\mathrm{Ag}$ Massive Sulfide Deposits in the Evolution and Facies Architecture of a 1.9 Ga Marine Volcanic Arc, Skellefte District, Sweden
}

\author{
Rodney L. AlLEN, \\ Volcanic Resources Ltd., Morteveien 57, Hundvåg, 4085 Stavanger, Norway \\ PÄr WEIHED, \\ Geological Survey of Sweden, P.O. Box 670, S-751 28 Uppsala, Sweden \\ AND SVEN-ÅKE SVENSON \\ Boliden AB, S-93681 Boliden, Sweden
}

\begin{abstract}
The Skellefte mining district occurs in an Early Proterozoic, mainly 1.90-1.87 Ga (Svecofennian) magmatic province of low to medium metamorphic grade in the Baltic Shield in northern Sweden. The district contains over 85 pyritic $\mathrm{Zn}-\mathrm{Cu}-\mathrm{Au}-\mathrm{Ag}$ massive sulfide deposits and a few vein Au deposits and subeconomic porphyry $\mathrm{Cu}-\mathrm{Au}-\mathrm{Mo}$ deposits. The massive sulfide deposits mainly occur within, and especially along the top of, a regional felsic-dominant volcanic unit attributed to a stage of intense, extensional, continental margin arc volcanism. From facies analysis we interpret the paleogeography of this stage to have comprised many scattered islands and shallow-water areas, surrounded by deeper seas. All the major massive sulfide ores occur in belowwave base facies associations; however, some ores occur close to stratigraphic intervals of above-wave base facies associations, and the summits of some volcanoes that host massive sulfides emerged above sea level. Intense marine volcanism was superceded at different times in different parts of the district by a stage of reduced volcanism, uplift resulting in subregional disconformities, and then differential uplift and subsidence resulting in a complex horst and graben paleogeography. Uplift of the arc is attributed to the relaxation of crustal extension and the emplacement of granitoids to shallow crustal levels. A few massive sulfide ores formed within the basal strata of this second stage. The horst and graben system was filled by prograding fluvial-deltaic sediments and mainly mafic lavas, and during this stage the Skellefte district was a transitional area between renewed arc volcanism of more continental character to the north, and subsidence and basinal mudstone-turbidite sedimentation to the south. This whole volcanotectonic cycle occurred within 10 to 15 m.y.

We define 26 main volcanic, sedimentary, and intrusive facies in the Skellefte district. The most abundant facies are (1) normal-graded pumiceous breccias, which are interpreted as syneruptive subaqueous mass flow units of pyroclastic debris, (2) porphyritic intrusions, and (3) mudstone and sandstone turbidites. Facies associations define seven main volcano types, which range from basaltic shields to andesite cones and rhyolite calderas. Despite this diversity of volcano types, most massive sulfide ores are associated with one volcano type: subaqueous rhyolite cryptodome-tuff volcanoes. These rhyolite volcanoes are 2 to $10 \mathrm{~km}$ in diameter, 250 to $1,200 \mathrm{~m}$ thick at the center, and are characterized by a small to moderate volume rhyolitic pyroclastic unit, intruded by rhyolite cryptodomes, sills, and dikes. Massive sulfide ores occur near the top of the proximal (near vent) facies association. The remarkable coincidence in space and time between the ores and this volcano type indicates an intimate, genetic relationship between the ores and the magmatic evolution of the volcanoes.

Many of the massive sulfide ores occur within rapidly emplaced volcaniclastic facies and are interpreted to have formed by infiltration and replacement of these facies. Some of the ore deposits have characteristics of both marine massive sulfides and subaerial epithermal deposits. We suggest that massive sulfides in the Skellefte district span a range in ore deposit style from deep-water sea-floor ores, to subsea-floor replacements, to shallow-water and possibly subaerial synvolcanic replacements. Facies models are provided for the mineralized rhyolite volcanoes and volcanological guides are provided for exploration for blind ores within these volcanoes.
\end{abstract}

\section{Introduction}

THE Skellefte district is one of the most important mining districts in Sweden. The district covers an area of 120 by 30 $\mathrm{km}$ in northern Sweden (Fig. 1) and contains over 85 pyritic $\mathrm{Zn}-\mathrm{Cu}-\mathrm{Au}-\mathrm{Ag}$ massive sulfide deposits. Twenty-one deposits have been mined since 1924 and five are currently in operation (by the Boliden company). These deposits cover a wide range of size, metal grades, and economic viability (Table 1 , Figs. 2 and 3). Fifty-two deposits contain 100,000 metric tons (t) or more and together provide a total premining tonnage for the district of $161 \mathrm{Mt}$ (million metric tons) with an average grade of $1.9 \mathrm{~g} / \mathrm{t} \mathrm{Au}, 47 \mathrm{~g} / \mathrm{t} \mathrm{Ag}, 0.7$ percent $\mathrm{Cu}, 3.0$ percent $\mathrm{Zn}, 0.4$ percent $\mathrm{Pb}, 0.8$ percent $\mathrm{As}$, and 25.6 percent $\mathrm{S}$. The median deposit size is $1.1 \mathrm{Mt}$ (Fig. 2). High Au, As, Sb, and Hg contents are common. The Boliden mine (1925-1967) was the largest gold deposit in Europe and the world's largest arsenic producer (Grip and Wirstam, 1970); however, current stringent controls on As and Sb levels in the smelter and refinery have resulted in several deposits being uneconomic, including Rakkejaur, the largest deposit in the district.

In geologic terms the Skellefte district is an Early Protero- 

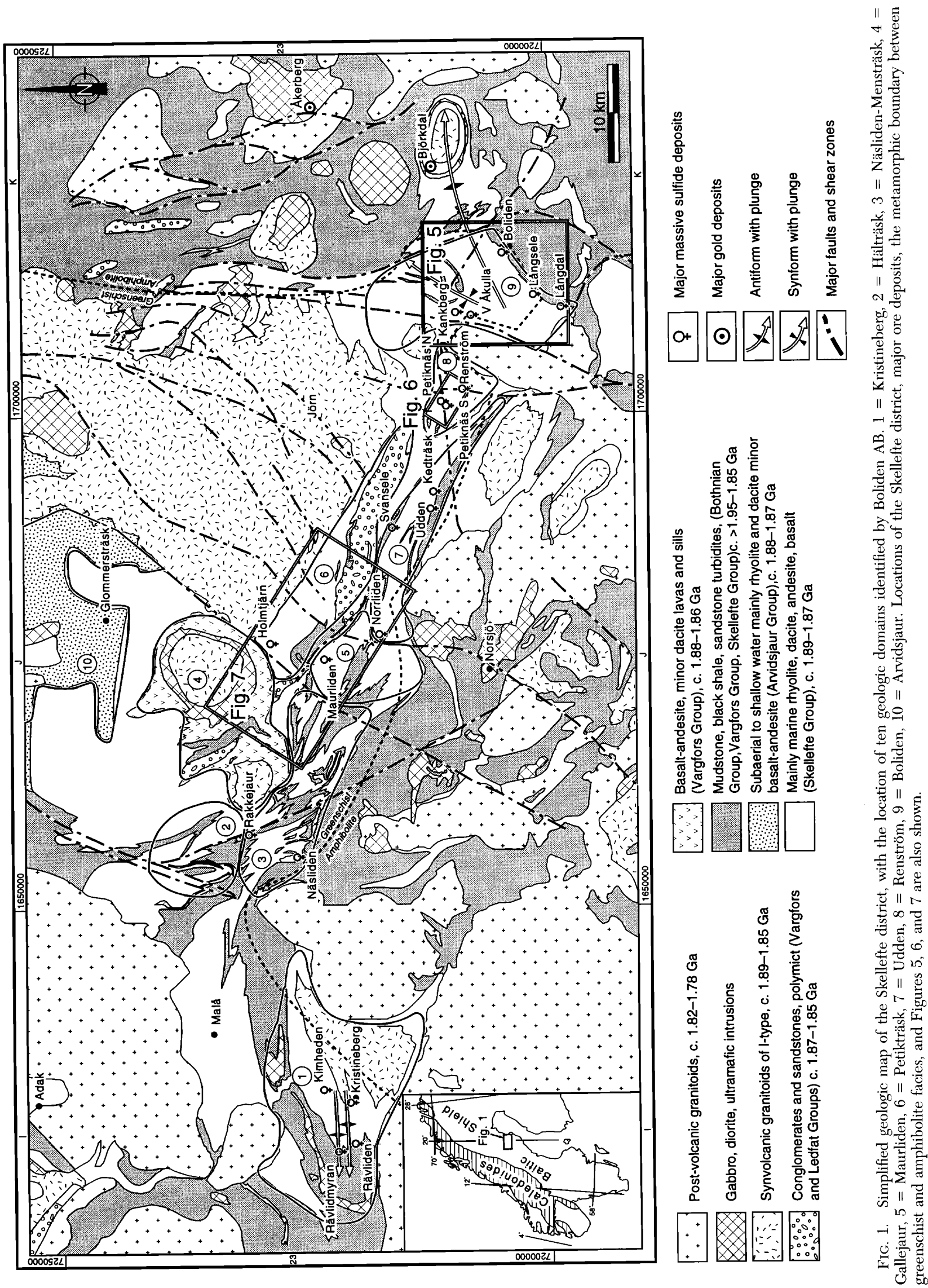


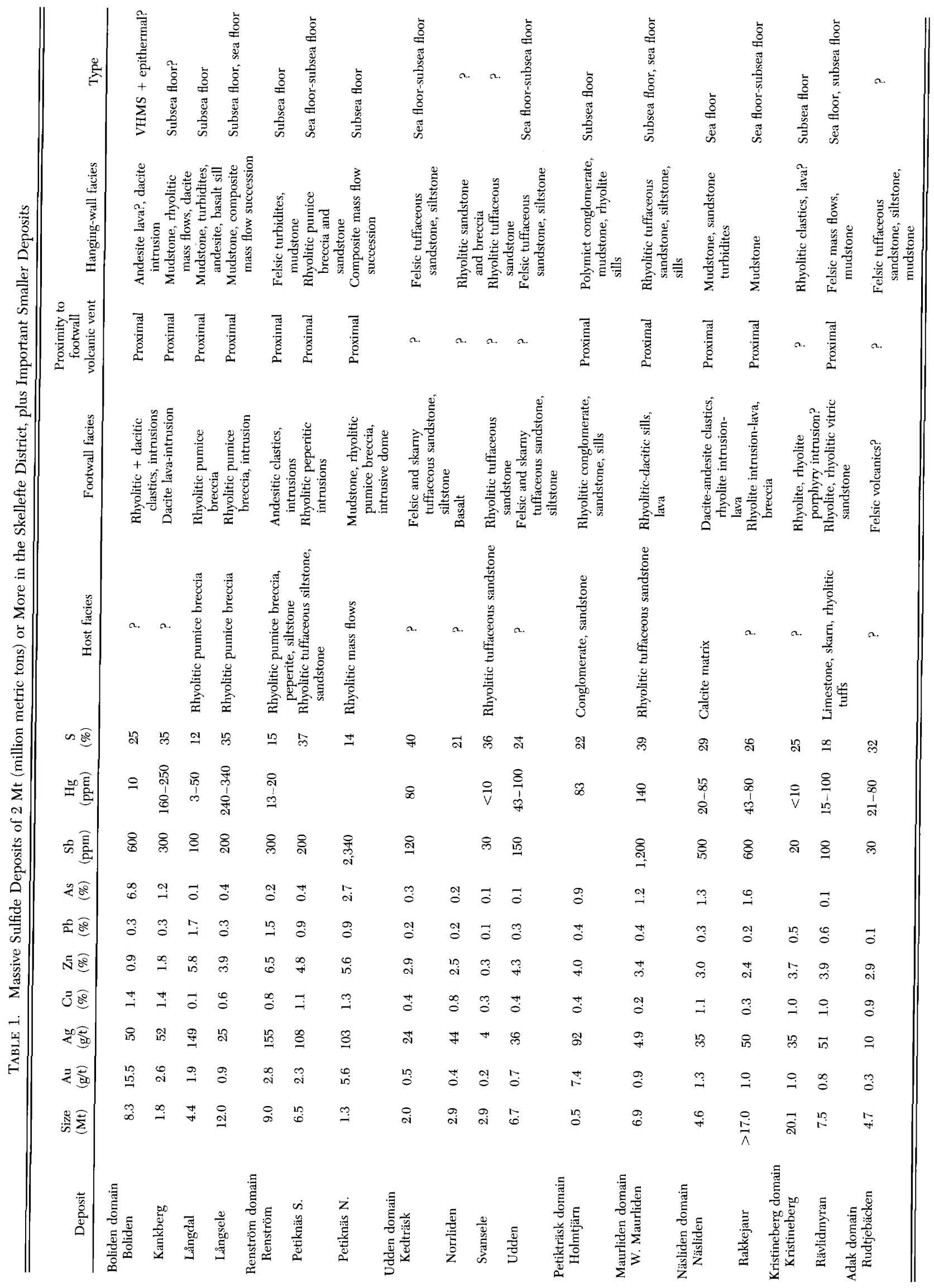




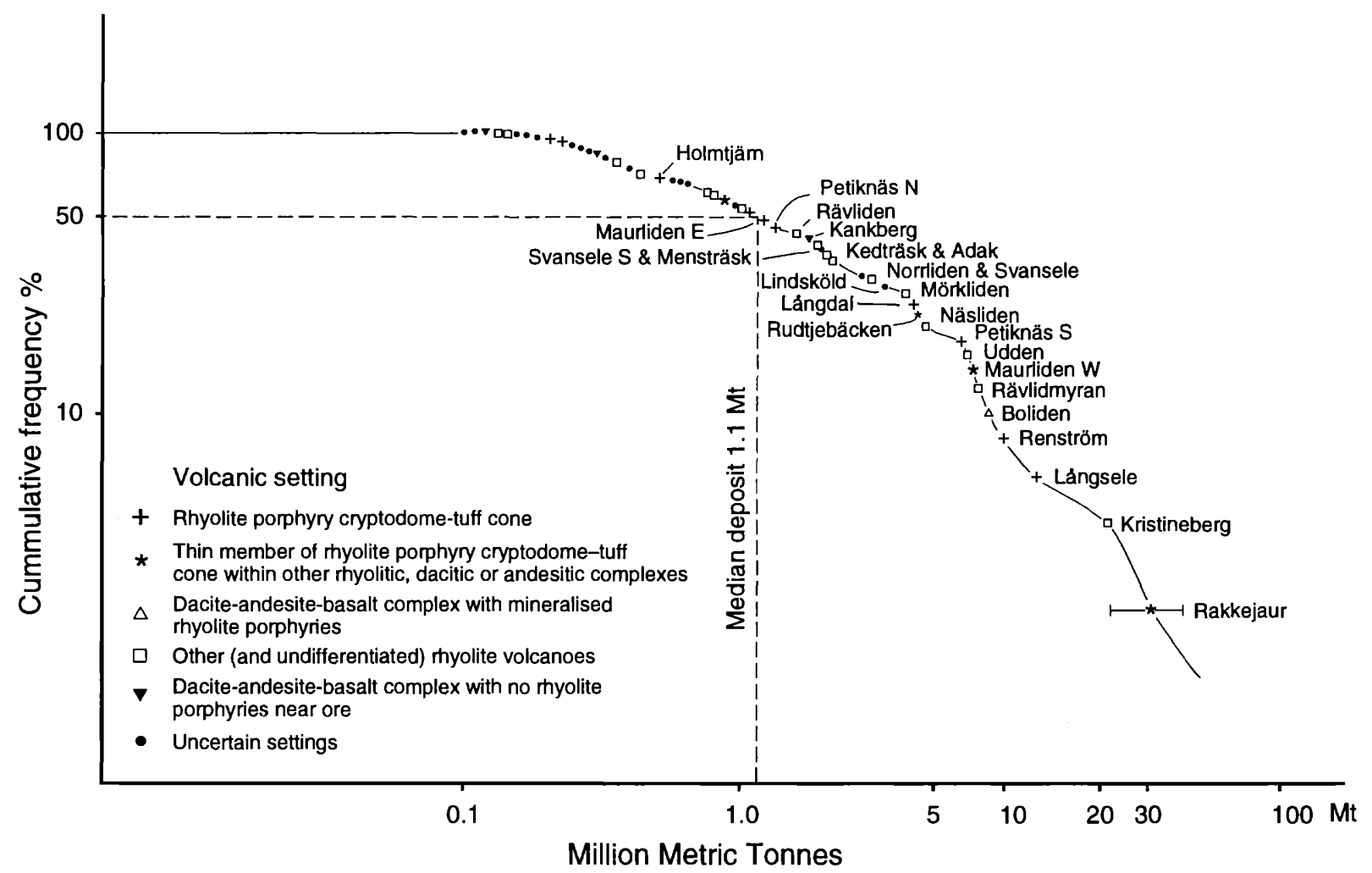

FIG. 2. Tonnage-frequency distribution and volcanic setting of the 52 known massive sulfide deposits of $0.1 \mathrm{Mt}$ or more in the Skellefte district.

zoic, mainly 1.90 to $1.87 \mathrm{Ga}$ (Svecofennian) felsic magmatic region of low to medium metamorphic grade in the Baltic Shield (Fig. 1). The massive sulfide ores occur within a thick volcanic succession and typically close to interbedded or overlying sedimentary units with dark, locally graphitic mudstone. In addition to massive sulfide deposits the district contains vein gold deposits and low-grade porphyry $\mathrm{Cu}$-Au-Mo deposits (Weihed et al., 1992), which are not discussed in this paper. The felsic volcanic rocks have been interpreted mainly as pyroclastic rocks and attributed to violent explosive submarine volcanism at large caldera volcanoes scattered throughout the district (Lundberg, 1980; Rickard, 1986; Vivallo and Claesson, 1987). Regional stratigraphy is complex and laterally variable and several stratigraphic schemes have been proposed (Eklund, 1923; Grip, 1951; Gavelin, 1955a; Kautsky, 1957; Helfrich, 1971; Lundberg, 1980; Weihed et al., 1992). The district is generally regarded as having formed between a continental landmass to the north (Arvidsjaur Volcanics) and a deep-marine sedimentary basin to the south (Bothnian basin). Depositional environments have been interpreted as mainly deep water, but shallowing upward through the stratigraphy and northward to the continental environment (Eklund, 1923; Lundberg, 1980; Zweifel, 1982). Based mainly on geochemistry the district has been interpreted as an ancient volcanic arc, and more specifically as an island arc (Hietanen, 1975; Lundberg, 1980; Rickard, 1986; Weihed et al., 1992), and an inter- or intra-arc rift within a continental margin arc (Vivallo and Claesson, 1987). Traditionally the massive sulfides were regarded as structurally controlled replacement ores related to hydrothermal activity of pre- or postmetamorphic granitoids (Högbom, 1928; Gavelin, 1955b). Some workers noted an association between the massive sulfide ores and rhyolite porphyries (Jonsson in Rickard, 1986). Rickard and Zweifel (1975) reinterpreted the ores as deformed and metamorphosed synvolcanic ore deposits analogous to the Miocene kuroko deposits of Japan, and in most recent publications the ores are interpreted as exhalative sea-floor deposits (Rickard, 1986). Recently, geologists of the Boliden company have subdivided the district into ten geologic domains (Fig. 1) according to differences in the style, composition, economic viability, and host rocks of the ores.

Despite only 1 percent or less outcrop due to extensive covering by late Quaternary glacial sediments, exploration success has been very high. Most of the ore deposits were discovered by tracing strings of mineralized boulders in the glacial tills back to their bedrock source, and by airborne and ground electromagnetic surveys (EM). However, easy targets within $250 \mathrm{~m}$ of the surface are now almost exhausted. Exploration has entered a new phase of deeper, geologically led exploration. In this exploration environment, more geologic guides to ore are required to continue exploration success, and this has been an important motivation for the present study.

Our initial observations of volcanic rocks in the Skellefte district suggested that new and more detailed interpretations could be made for many of the volcanic rock types, the depositional environments, the stratigraphic and structural architecture of the district, and the style and setting of ore deposition. 

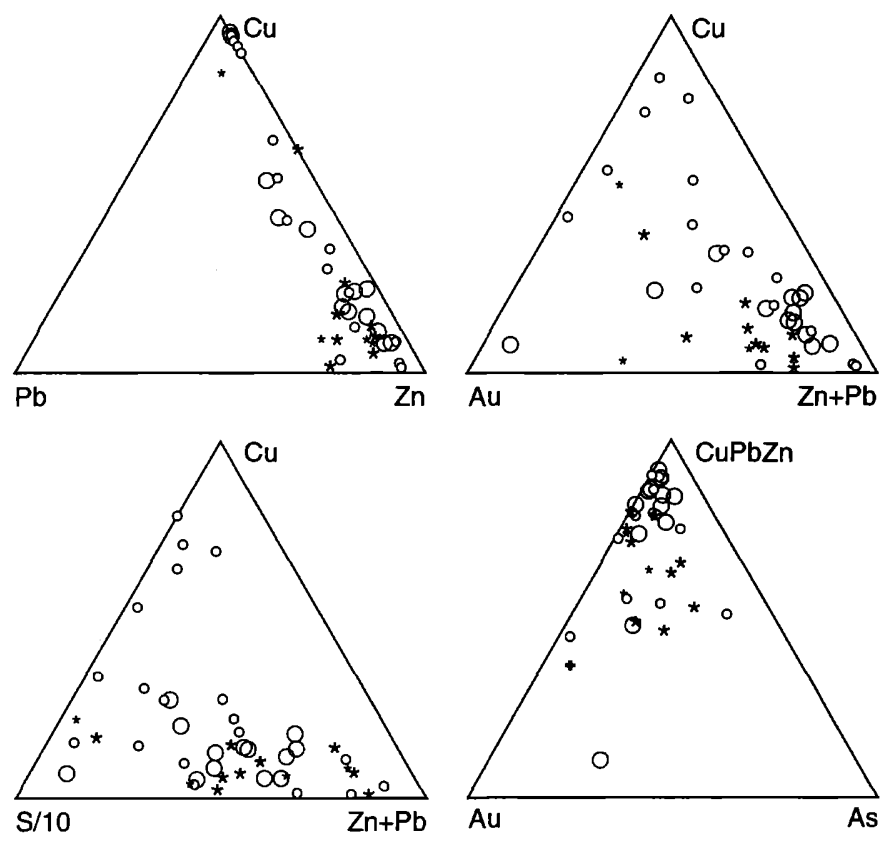

FIG. 3. Metal ratio plots for massive sulfide ores in the Skellefte district. Stars represent rhyolite cryptodome-tuff volcanoes (including thin members). Circles represent other settings. Large symbols represent deposits larger than the median deposit size (1.1 Mt) and small symbols represent deposits smaller than the median.

The aims of this study were to follow up these initial observations with a field-oriented and facies-oriented regional analysis of the volcanic and sedimentary setting of massive sulfide deposits in the district. Particular emphasis was placed on the fundamental steps of identifying primary rock textures and emplacement units. Drill core was used extensively to construct continuous graphic logs of the rock successions and to resolve contact relationships and relationships between mineralization and host rocks. Seven of the ten geologic domains were studied (Hälträsk, Gallejaur, Maurliden, Petikträsk, Renström, Boliden, and Arvidsjaur), including the settings of 14 massive sulfide deposits. Petrography and geochemical analyses were used to compliment field interpretations.

In this paper we provide a summary of the regional geology, the characteristics of the massive sulfide deposits, and the results of the facies analysis in a series of logical interpretative steps. Despite the greenschist to lower amphibolite mineralogy and fabrics in the rocks, we use primary volcanic and sedimentary terminology for brevity and to emphasize the primary features of the rocks. Relict primary textures are locally well preserved on slightly weathered outcrop surfaces, in drill core and in polished rock slices. In order to explain facies relationships, variable regional stratigraphy and unconformities, we propose a new stratigraphic framework for the district. This stratigraphy is interpreted in terms of the evolution of an extensional continental margin volcanic arc; however, neither the facies analysis nor the stratigraphic scheme are dependent on this volcanic arc model. We propose that most of the massive sulfide ores are an intimate part of small to moderate size, marine, rhyolite cryptodome-tuff volcanoes rather than large pyroclastic caldera volcanoes, and that many ores formed by infiltration and replacement of subsea-floor strata rather than by exhalation on the sea floor. We provide facies models for the mineralized rhyolite volcanoes and volcanological guides for exploration of blind ores within these volcanoes.

\section{Regional Stratigraphy}

The Skellefte mining district coincides with a mainly northwest-southeast-trending belt of Svecofennian volcanic, sedimentary and intrusive rocks (Fig. 1). This belt is characterized by abundant moderately to strongly deformed, gray, diagenetically and hydrothermally altered, marine volcanic rocks. Basement to the belt is not exposed. The belt has an apparently conformable boundary to the south with an extensive metasedimentary region with abundant granitoids (Bothnian basin). To the north the Skellefte district has a poorly defined boundary with an extensive region of less deformed, less altered, mainly brown continental felsic volcanic rocks, intrusions, and minor sediments (Arvidsjaur Group).

Throughout the Skellefte district there is a simple firstorder regional stratigraphy consisting of a thick volcanic unit (Skellefte Group) overlain by mainly sedimentary successions (Fig. 1). Most previous workers agree with this pattern; however, many alternatives have been presented for other aspects of the stratigraphy, regional correlations, and timing and magnitude of deformation (Eklund, 1923; Grip, 1951; Gavelin, 1955a; Kautsky, 1957; Helfrich, 1971; Lundberg, 1980; Claesson, 1985; Weihed et al., 1992). Grip (1951) and Gavelin (1955a) proposed that the Skellefte Group volcanics were overlain by an argillitic unit (their "Phyllite series"), and then the Arvidsjaur volcanics to the north. This succession was then folded, uplifted, intruded by Jörn- and Revsund-type granitoids, and unconformably overlain by conglomerate (their "Vargfors series"). Kautsky (1957) emphasized that argillites were intercalated within the Skellefte Group (his "Maurliden series"), that this complex was intruded by Jörn granitoids, folded, uplifted, and then unconformably overlain by a sedimentary group consisting of sedimentary breccia and conglomerate (his Mensträsk breccia and Vargfors conglomerate) and more argillites (his Elvaberg slates). Helfrich (1971) produced a more dynamic version of Kautsky's model with units interfingering and overlapping in time and space. The most recent comprehensive scheme is that by Lundberg (1980) and is similar to Gavelin's (1955a) except that the Revsund granites are recognized as younger than the Vargfors Group. Our work suggests that parts of the previous stratigraphic schemes are correct. However, we interpret the main stratigraphic units to have conformable, disconformable, and interfingering contacts, and that there is no major regional angular unconformity within the succession. We provide a new stratigraphic framework expressed in Figure 4A in terms of time-stratigraphic relationships, and in Figure $4 \mathrm{~B}$ in terms of lithostratigraphic and structural relationships. This stratigraphic framework is synthesized from new mapping and reinterpretation of several domains (Figs. 5, 6, and 7), and construction of many stratigraphic columns (Fig. 8). We have used existing nomenclature wherever possible; however, it is necessary to redefine several stratigraphic units.

\section{Skellefte Group}

The Skellefte Group is redefined as the lowest stratigraphic unit dominated by juvenile volcaniclastic rocks, porphyritic 

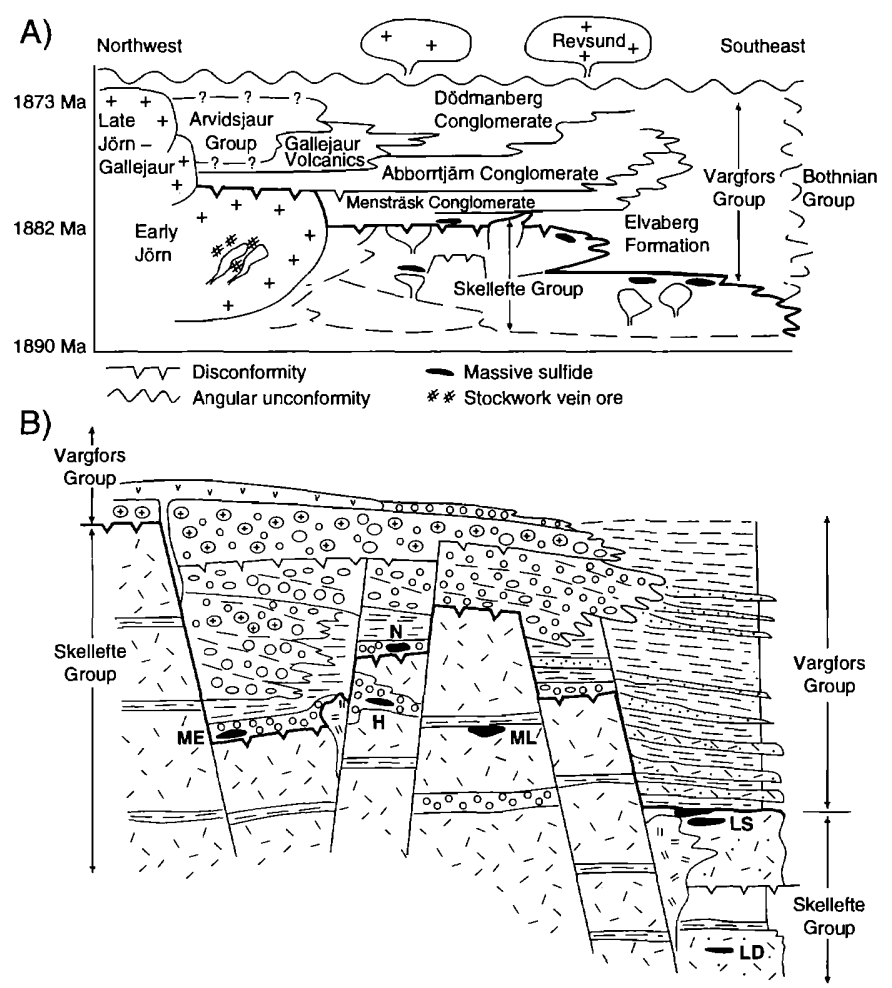

FIG. 4. A. Regional time-stratigraphic relationships, lithostratigraphy, and location of massive sulfide deposits in the Skellefte district as proposed in this study. Nomenclature is modified after Grip (1951), Gavelin (1955a), Kautsky (1957), Helfrich (1971), and Lundberg (1980). The diagram is drawn as a schematic pseudosection from the north and northwest of the district (left side of diagram) to the south and southeast (right side). However, the diagram emphasizes time-stratigraphic relationships, and consequently, the correct structural configuration of the units cannot be shown on the same diagram. B. Lithostratigraphic and structural relationships of the Skellefte Group and Vargfors Group during the early to middle stages of Vargfors Group sedimentation. Stratigraphic setting of the Mensträsk (ME), Holmtjärn (H), Nicknoret (N), Maurliden (ML), Långsele (LS), and Långdal (LD) massive sulfide deposits are shown. Circle, dot, and horizontal dash patterns correspond to conglomerate, sandstone, and siltstone, respectively. Random dashes correspond to volcanic units.

intrusions, and lavas (Fig. 9). Intercalated sedimentary rocks are included in the group and comprise gray to black mudstone, volcaniclastic siltstone, sandstone and breccia-conglomerate, volcaniclastic rocks with a lime matrix in the center of the district, and rare limestone. Overlying sedimentary units are excluded from the Skellefte Group and incorporated into the Vargfors Group. The Skellefte Group contains most of the massive sulfide ores and has an extremely variable internal stratigraphy. Numerous formations can be mapped and correspond to distinct units within individual domains (Figs. 5, 6, and 7); however, no formations could be traced from one domain to the next. The maximum measured stratigraphic thickness of the Skellefte Group is $3 \mathrm{~km}$ in the Petikträsk domain (Fig. 8), but the base of the group is nowhere exposed. A U-Pb zircon date suggests that the upper part of the group in the Petikträsk domain is $1882 \pm 8 \mathrm{Ma}$ (Welin, 1987).

Rhyolitic rocks are abundant in the Skellefte Group; however, knowledge of the group has been based mainly on stud- ies around the mines and in the center of the district, which is the best exposed and most rhyolitic area. Our calculation of the percentage area of different volcanic compositions (Fig. 10 ) indicates that the group is neither overwhelmingly rhyolitic nor bimodal as previously suggested. The proportions of rhyolite, dacite, andesite, and basalt vary greatly between different domains. For example, andesite predominates in the Hälträsk domain, dacite in the Boliden domain, and rhyolite in the Petikträsk domain (Fig. 10). Bimodal compositions are restricted to particular stratigraphic intervals or areas within individual domains (e.g., Långdal mine sequence in Boliden domain; Figs. 5 and 8).

\section{Vargfors Group}

The Skellefte Group is overlain by fine-grained and coarsegrained sedimentary successions with locally abundant intercalated volcanic rocks. These overlying successions are interpreted in this study to have mainly gradational and interfingering, conformable contact relationships with each other (Figs. 4 and 8) and are consequently regarded as one stratigraphic group, the redefined Vargfors Group (Fig. 4A and B). The main formations comprise the Mensträsk conglomerate, which is volcanic breccia-conglomerate of mainly Skellefte Group clasts (Fig. 11B and C) and which includes the Mensträsk breccia of Kautsky (1957). Elvaberg Formation comprises argillitic sedimentary rocks with varying abundance of sandstone and breccia interbeds (Fig. 11A) and corresponds to the Elvaberg slates and Phyllite series of previous workers. Limestone beds and a lime matrix occur sporadically within Mensträsk conglomerate and Elvaberg Formation, especially near the base of the Vargfors Group. The Abborrtjärn conglomerate (Kautsky, 1957) consists mainly of polymict conglomerate and sandstone with abundant Jörn-type granitoid clasts and commonly Skellefte Group volcanic clasts (Fig. 11D). Dödmanberg conglomerate (Kautsky, 1957) consists mainly of red and green polymict conglomerate and sandstone with a range of clast types including red-brown Arvidsjaur-type volcanic and sedimentary rocks, green mafic volcanic rocks, granitoids, white vein quartz and jasper. The Gallejaur volcanics comprise green, moderate to high $\mathrm{Mg}$ basalt lavas and intrusions (including the Vargfors Andesite of Kautsky, 1957), and other subordinate basalt, andesite, dacite, rhyolite, and interbedded sedimentary rocks. Moderate to high-Mg basalts in the upper part of the Skellefte Group and in the Elvaberg Formation are interpreted as sills and dikes related to the Gallejaur volcanics.

The contact relationship between the Skellefte Group and Vargfors Group varies, even within individual domains, from conformable (e.g., Hälträsk, Långdal, Långsele) to disconformable (e.g., Långtjärn, Petikträsk, Holmtjärn, Boliden; Figs. 4 and 8). Disconformities were mainly recognized at the base of conglomerate units; however, they also occur at the base of fine-grained clastic rocks of the Elvaberg Formation at Boliden (Fig. 8C). Disconformities also occur within the Vargfors Group (Fig. 8L); but we find no evidence within or at the base of the Vargfors Group for the major structural break, folding event, and regional angular unconformity interpreted by most previous workers. Furthermore, the absence of clasts eroded from lithified Elvaberg Formation mudstones, despite the vast extent of these mudstones, argues 


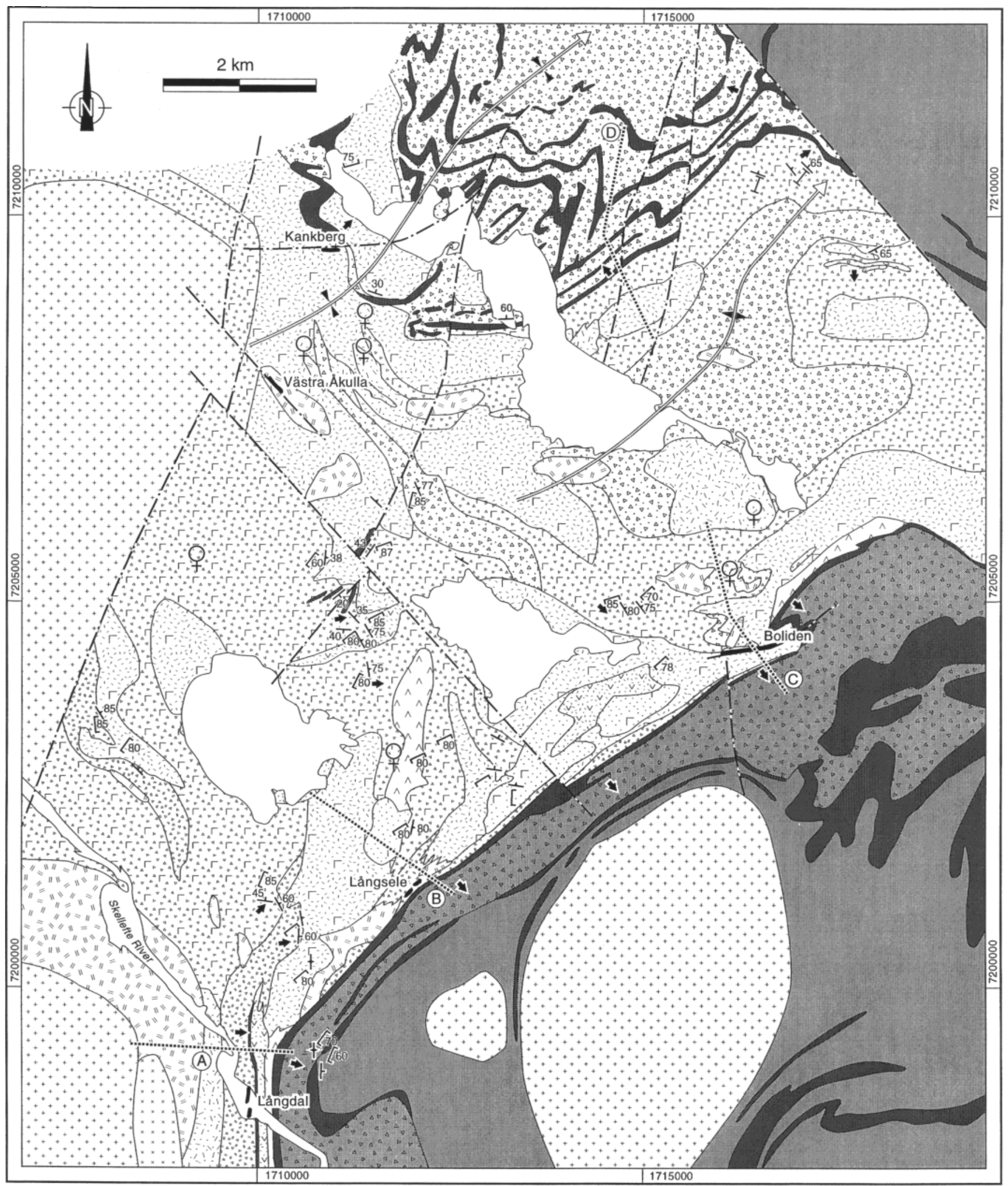

FIG. 5. Geologic map of the main part of the Boliden domain showing the structure and distribution of main facies, volcanic compositions, and ore deposits. Locations of the stratigraphic columns in Figure 8 are marked by dotted lines. See Figure 6 for legend. 


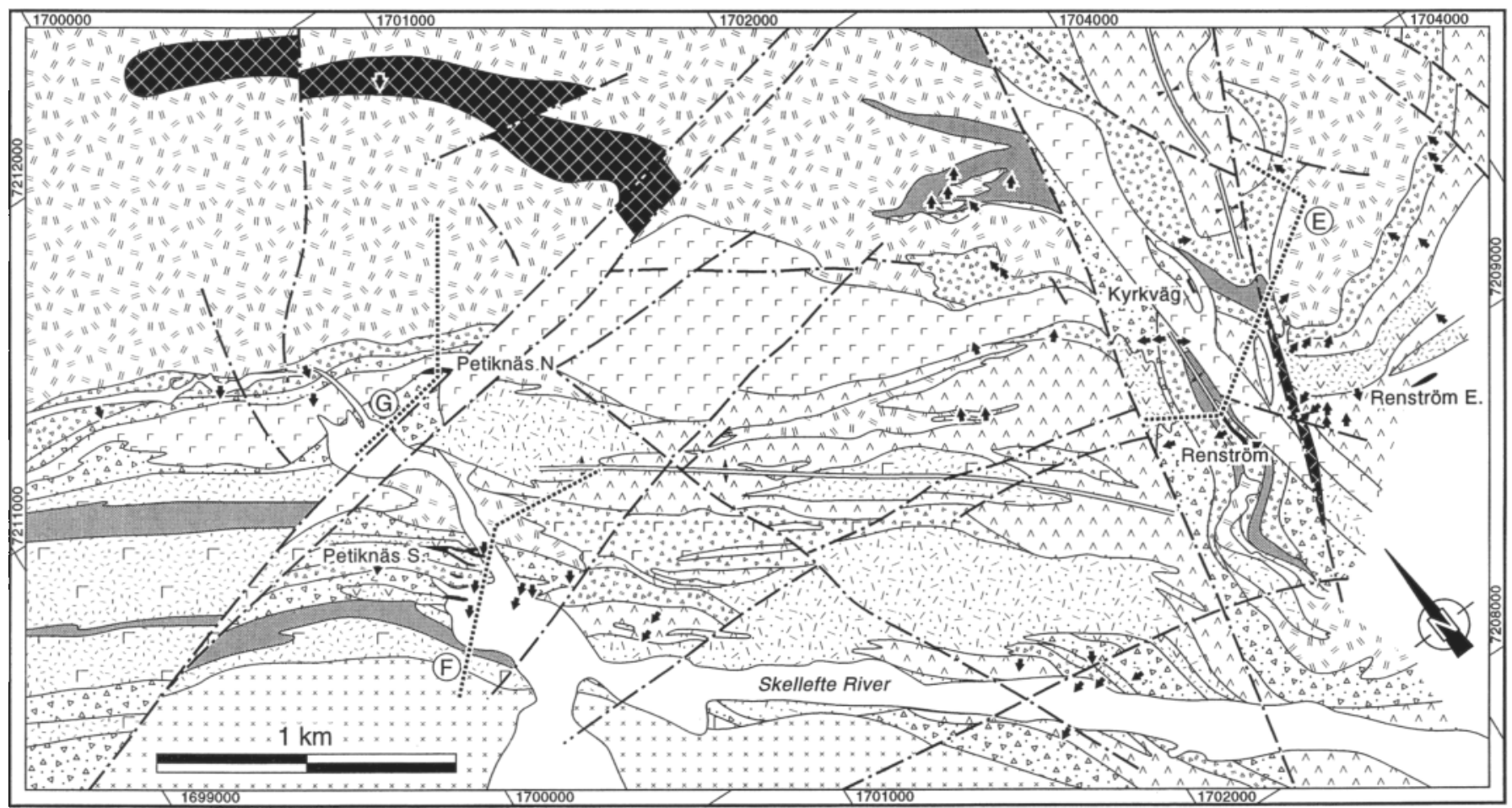

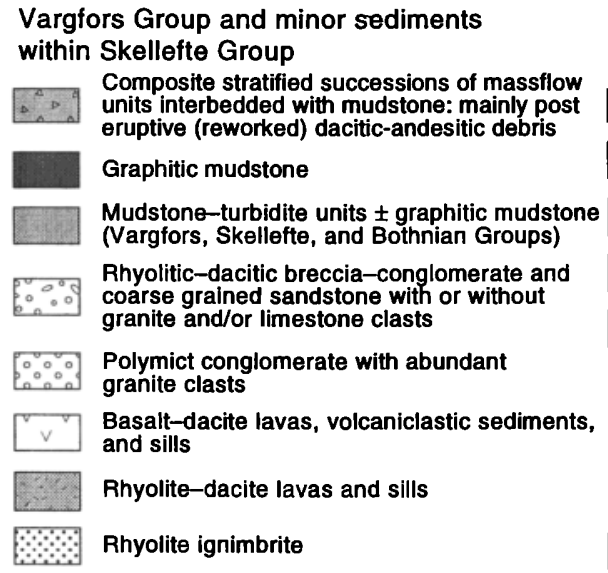

Vargfors Group and minor sediments

Composite stratified successions of massflow units interbedded with mudstone: mainly post eruptive (reworked) dacitic-andesitic debris

Graphitic mudston

Mudstone-turbidite units \pm graphitic mudston (Vargfors, Skellefte, and Bothnian Groups) Rhyolitic-dacitic breccia-conglomerate and coarse grained sandstone with or without

ith abundant ranite clasts

and sills

Rhyolite ignimbrite

Skellefte Group

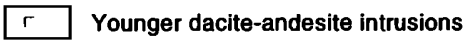

Very crystal-rich older dacite intrusions

Moderately to strongly feldspar porphyritic, older dacite intrusions

Basalt-andesite extrusives: lava, hyaloclastite, and stratified to massive clastic units Basalt-andesite intrusions

Composite stratified successions of mass flow Composite stratified successions of mass flow

$\therefore \cdot \Delta \cdot$ mainly syn-eruptive pumiceous, and postmainhy syn-eruptive pumiceous, and
eruptive (reworked) thyolitic units

Feldspar phyric dacitic ( \pm low sillica rhyolite silicic andesite) syn-eruptive pumiceous silicic andesite) syn-eruptive pumiceous
mass flows \pm reworked volcaniclastics Undifferentiated felsic volcanics

$\therefore$ Fine grained myolite lavas, intrusions, and hyaloclastites

Q:- Quartz-feldspar phyric myolitic syn-eruptive

$\because \because$ pumiceous mass flows and fallout

"III Strongly quartz-feldspar and feldspar porphyritic myolite intrusions, lavas, and hyaloclastites
Intrusive rocks

\section{$+\div$ Post-volcanic granites}

$2 * *:$ Syn-volcanic granites (Jöm, Gallejaur type)

Gabbro, dolerite intrusions

$\because \quad$ Ultra-mafic intrusions

\begin{tabular}{|c|c|}
\hline$\forall$ & Direction of younging \\
\hline & Ore/prospect \\
\hline & Fault and shear zone \\
\hline & Bedding \\
\hline & S1 and fiamme foliation \\
\hline & Main regional cleavage ( $\mathrm{S} 2$ \\
\hline & Synform with plunge \\
\hline$x$ & Antiform with plunge \\
\hline
\end{tabular}

Antiform with plunge

FIG. 6. Geologic map of the main part of the Renström domain showing the structure, and distribution of main facies, volcanic compositions, and ore deposits. Locations of the stratigraphic columns in Figure 8 are marked by dotted lines.

against the regional angular unconformity between the Elvaberg Formation and Vargfors Group conglomerates proposed by Grip (1951), Gavelin (1955a), and Lundberg (1980). In fact, where the Mensträsk conglomerate and Abborrtjärn conglomerate overlie mudstone units, they contain irregular softstate deformed mudstone clasts, scoured from an unlithified, presumably penecontemporaneous, mudstone substrate (Långtjärn, Nicknoret West, Fig. 8). The mapping of Svenson and Weihed (unpub. data, 1982-1990) in the Petikträsk re- gion, Bergman (in Weihed et al., 1992), and this study show that Vargfors Group rocks have the same cleavages, fold generations, and intensity of deformation as adjacent exposures of Skellefte Group. The interpretation perpetuated in the literature that the Skellefte Group is invariably very steeply dipping and the Vargfors Group gently dipping is incorrect. Both groups have steep and gentle dips. We suggest that apparent discordant contacts relate to misinterpreted stratigraphy and structure, and to faulted contacts. 


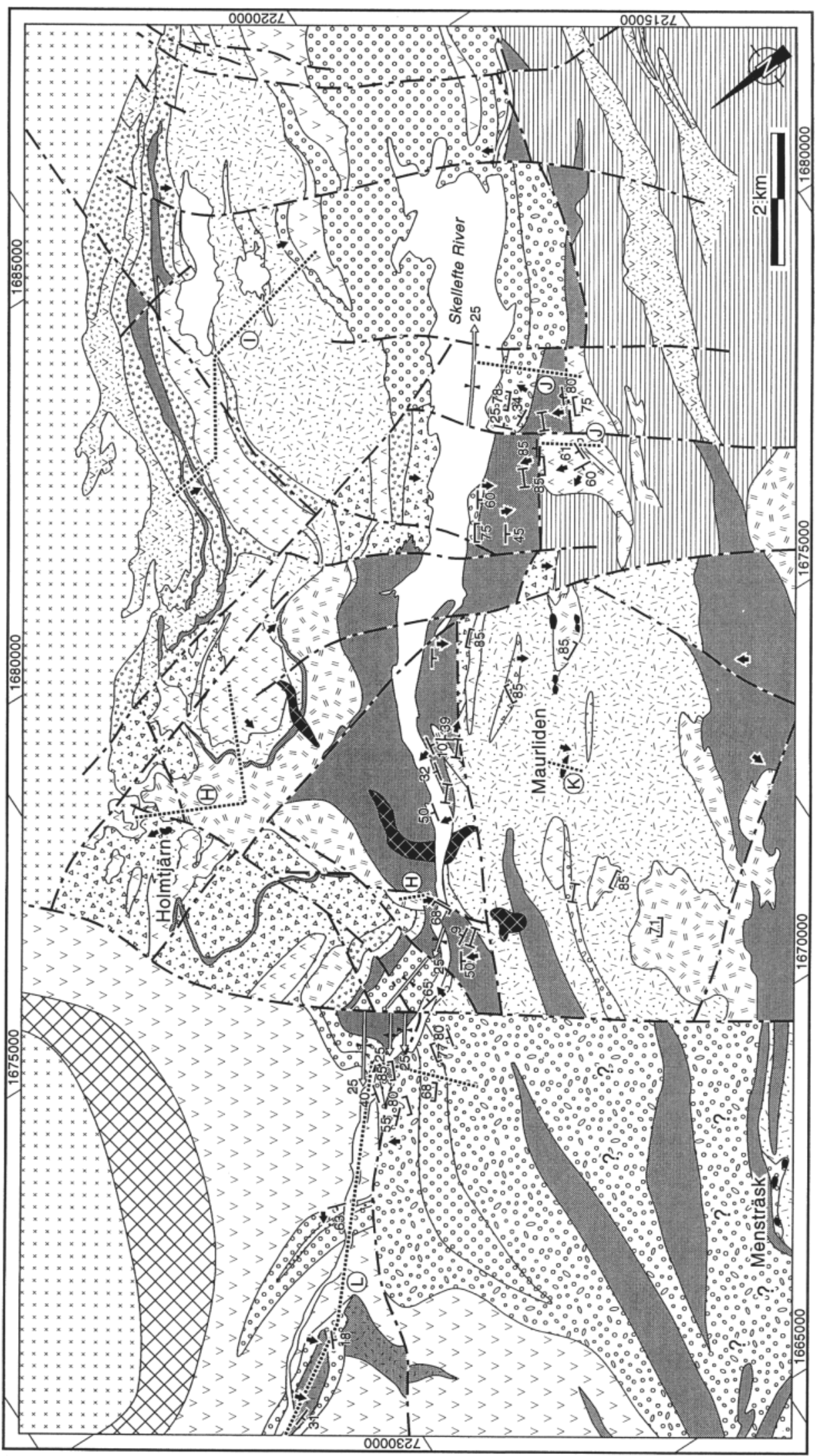

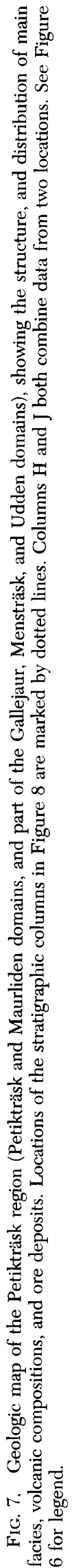




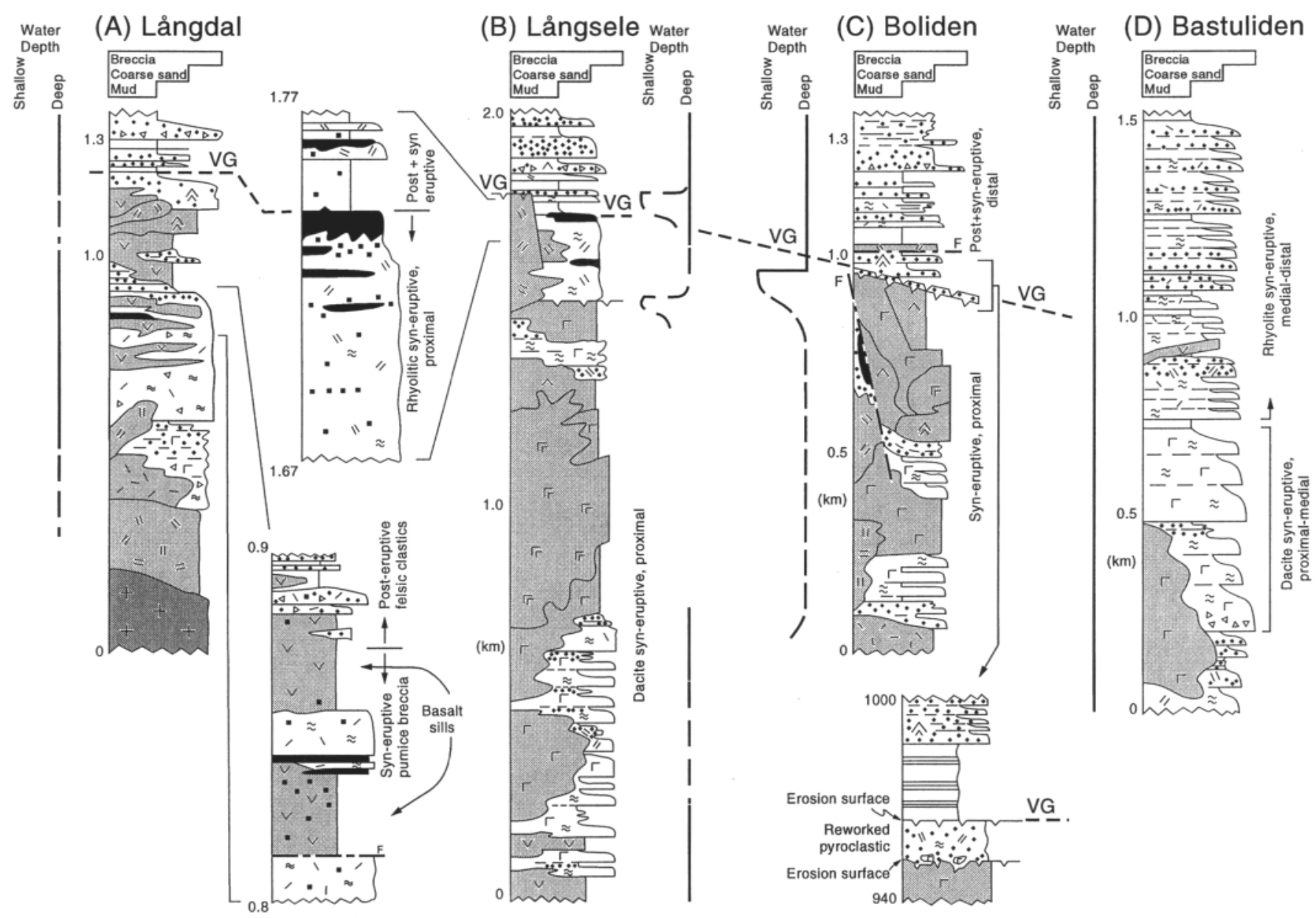

FIG. 8. Stratigraphic columns for the Skellefte district, showing facies relationships, contact relationships, vertical distribution of facies associations, interpreted water depth curves, and detailed stratigraphy of massive sulfide deposits. The columns are drawn in the format of graphic logs with grain-size profiles. Stratigraphic thicknesses are calculated true thickness. Locations of the columns are shown in Figures 5, 6, and 7.

The Vargfors Group reaches a minimum stratigraphic thickness of $4 \mathrm{~km}$ in the Nicknoret West-Gallejaur area (Fig. $8 \mathrm{~L}$ ); however, the top of the group is not exposed. U-Pb zircon dates of $1873 \pm 10 \mathrm{Ma}$ for the Gallejaur monzonite (Skiöld, 1988) and $1876 \pm 4$ Ma for the Gallejaur gabbro (Skiöld et al., 1993) that intrude into, and are geochemically related to, the Gallejaur volcanics give an indirect age for the upper Vargfors Group. A welded ignimbrite in the middle of the group (Figs. 7 and $8 \mathrm{~L}$ ) has yielded a U-Pb zircon date of $1877 \pm 3 \mathrm{Ma}$ (Billström and Weihed, 1996). These data, stratigraphic relationships with the Skellefte Group, and interpreted lateral equivalence with the Arvidsjaur Group (see below), suggest that the Vargfors Group ranges up to $10 \mathrm{~m} . \mathrm{y}$. younger than the Skellefte Group. The middle of the Vargfors Group is probably about $5 \mathrm{~m}$.y. younger than the top of the Skellefte Group in the central part of the district. These data support our interpretation of a conformable to disconformable contact with no major time gap and compressional deformation between the Skellefte and Vargfors Groups.

An important conclusion from our reinterpretion of the stratigraphy is that some massive sulfide ores occur in the lower part of the Vargfors Group, which was previously re- garded as completely unmineralized (Fig. 4). In particular, the description of Grip (1951) indicates that the Mensträsk ores occur within the Mensträsk conglomerate (Fig. 7). At the Holmtjärn mine, Skellefte Group volcanics are intercalated with Vargfors-like conglomerates and the ore occurs in a facies similar to the Mensträsk conglomerate (Fig. 8H). At Langsele and Boliden some minor mineralizations overlie the main massive sulfide lenses. These mineralizations occur in interbedded volcaniclastic sandstone, pumice breccia, and mudstone of the Elvaberg Formation (Fig. 8B).

\section{Arvidsjaur Group}

The Arvidsjaur Group is characterized by brown to red, subaerial, felsic to intermediate volcanic rocks including welded ignimbrite, ash-fall tuff, and volcaniclastic sedimentary rocks (Lilljequist and Svenson, 1974; B. Sjöblom, unpub. data). We do not redefine this group. Distinct Arvidsjaur Group volcanic detritus is unknown in the Skellefte Group and the earliest parts of the Vargfors Group but occurs in the Abborrtjärn conglomerate and especially the Dödmanberg conglomerate. This, and the similar radiometric ages of parts of the Arvidsjaur Group (1876 \pm 3 Ma, Skiöld et al., 1993), 


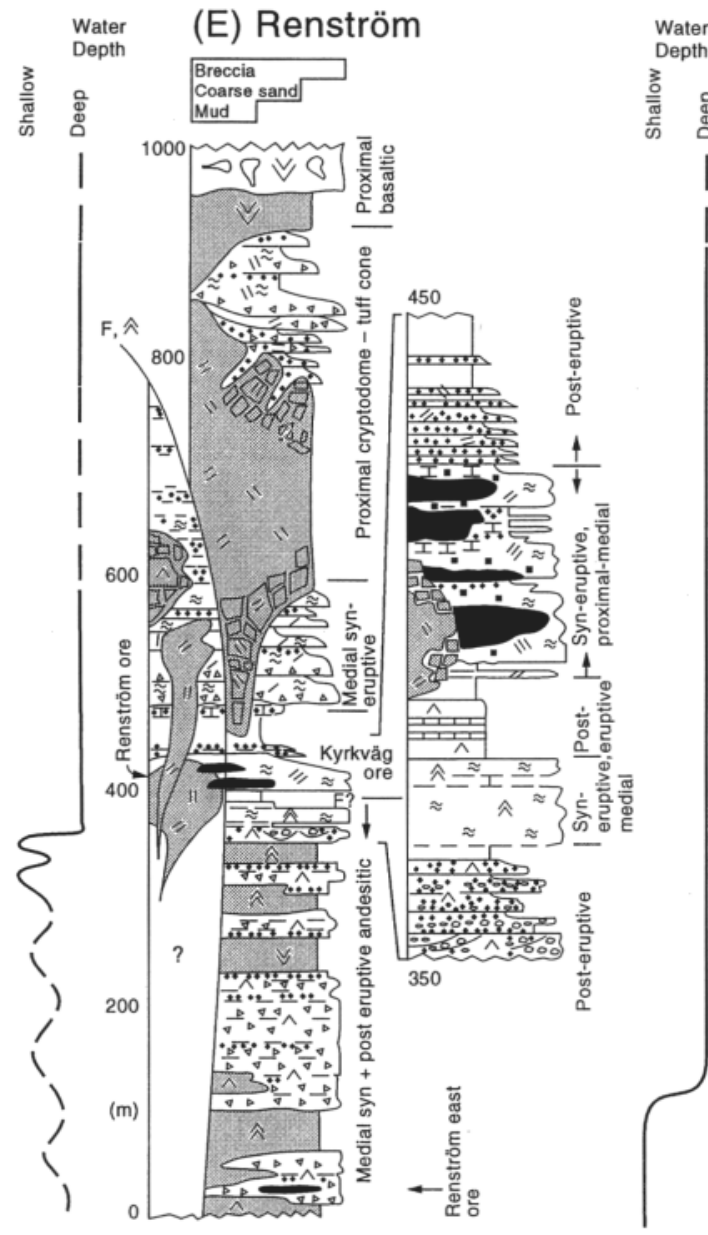

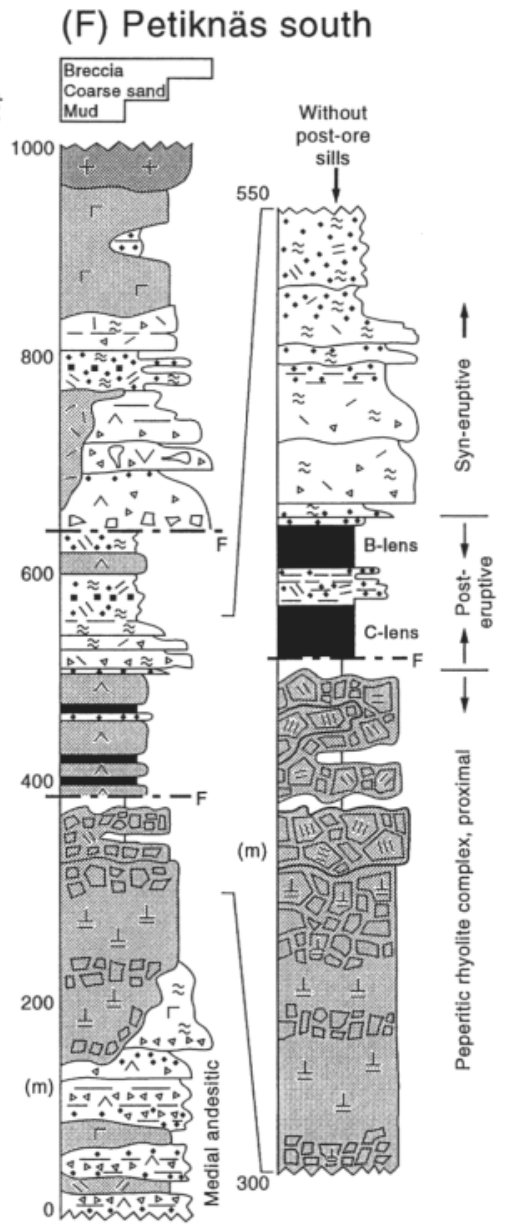

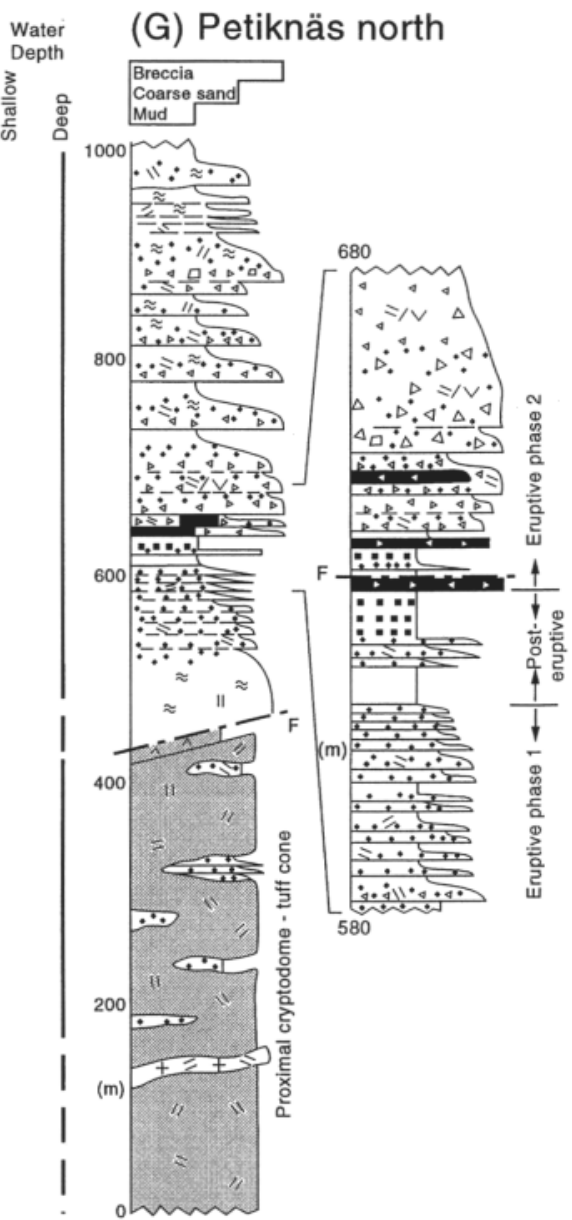

FIG. 8. (Cont.)

the ignimbrite in the Vargfors Group ( $1877 \pm 3 \mathrm{Ma}$, Billström and Weihed, 1996) and the Gallejaur Monzonite (1873 \pm 10 Ma, Skiöld, 1988) and Gallejaur Gabbro (1876 44 Ma, Skiöld et al., 1993) that intrude the Gallejaur volcanics, suggest that the Arvidsjaur and Vargfors Groups are lateral equivalents. It remains possible, but unsubstantiated, that the lower part of the Arvidsjaur Group is a subaerial lateral equivalent of the Skellefte Group as suggested in many previous stratigraphic schemes.

\section{Jörn granitoid suite}

The Jörn granitoid suite comprises the composite Jörn batholith at the northern margin of the Skellefte Group and several smaller plutons within and around the Skellefte Group (Fig. 1). The suite ranges from gabbro to granite and averages granodiorite or tonalite in composition. The early border phase of the Jörn batholith has a characteristic coarse quartz porphyritic texture that is similar to several porphyritic rhyolite intrusions within the Skellefte Group. Several features of the Jörn suite suggest that it may be comagmatic with Skellefte and Arvidsjaur volcanism, including compositions similar to those in the Skellefte Group, radiometric ages that span those of the Skellefte, Vargfors, and Arvidsjaur Groups, intrusive contacts with the Skellefte and Arvidsjaur Groups, and abundant clasts of early Jörn suite members in the middle and upper parts of the Vargfors Group (Lundberg, 1980; Claesson, 1985; Wilson et al., 1987). The latter point indicates that early members of the Jörn batholith were uplifted and eroded during deposition of the Vargfors Group. In the Skellefte Group, the Jörn-type granitoids intruded stratigraphically below the massive sulfide deposits, except for the small Rengård granitoid at the southern margin of the Renström domain (Fig. 6), which intruded stratigraphically above the Petiknäs and Renström deposits. The Jörn batholith hosts subeconomic porphyry Cu-Au-Mo mineralization (Weihed et al., 1987; Weihed, 1992).

\section{Structure}

The Skellefte district contains isoclinal to open, upright folds, cut by shear zones and numerous brittle faults (Fig. 1). Cleavage intensity varies greatly, and the metamorphic grade increases from greenschist facies in the center of the district to lower amphibolite facies to the west, south, and east. The main early folds, cleavage, lineation $\left(F_{2}, S_{2}, L_{2}\right)$, and shear zones trend parallel to and define the elongate belt. The main fold axes and lineations plunge moderately to the west in the west of the district, and moderately to steeply to the southeast and northeast in the east of the district, thus defining a re- 

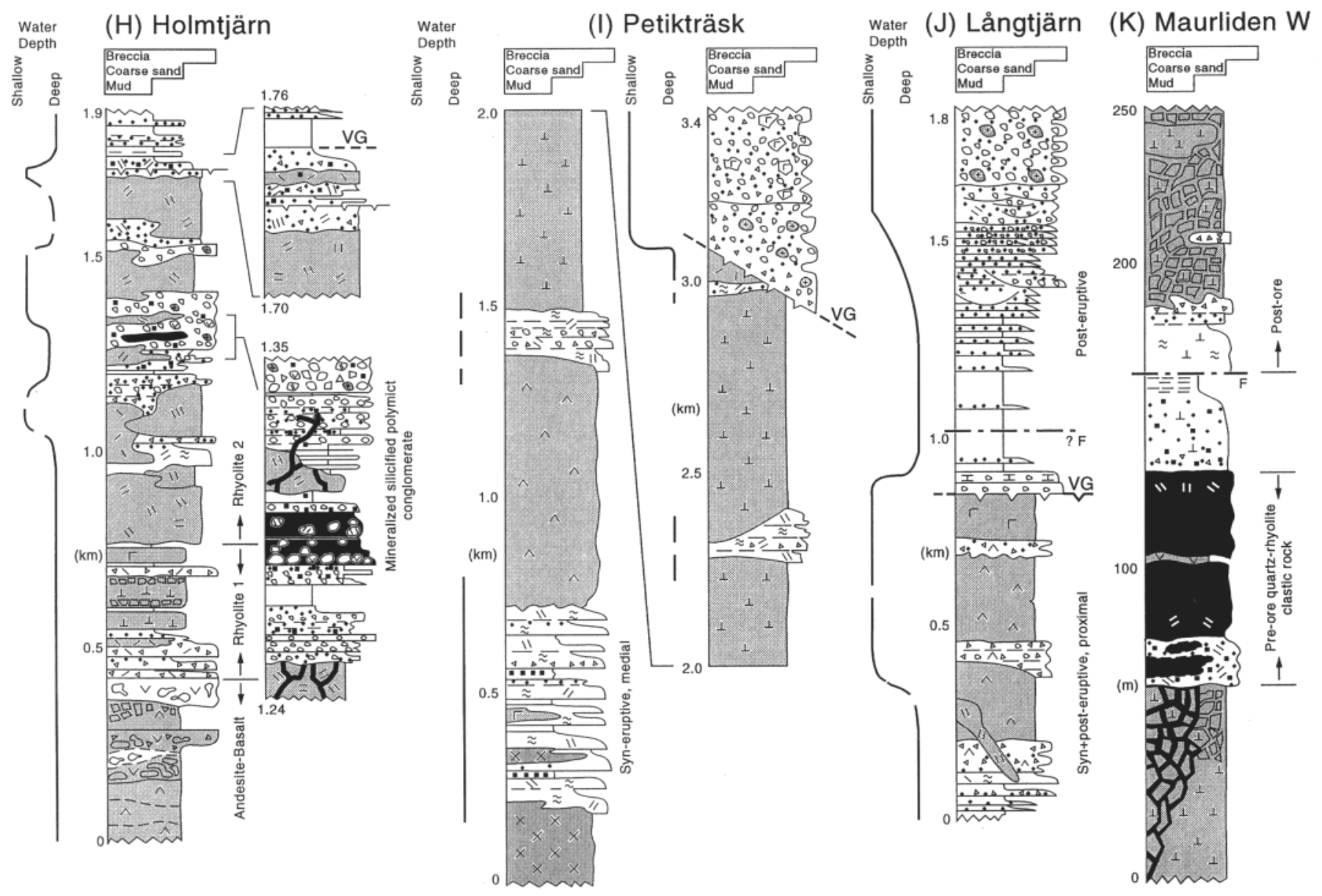

FIG. 8. (Cont.)

gional elongate structural arch. In the center of the district the main fold axes and lineations have mainly shallow to moderate plunges that alternate along strike from southeasterly to northwesterly (Fig. 7). The plunge reversals occur across northerly trending, steep, mainly dip-slip cross faults (Fig. 7) and open to tight folds $\left(\mathrm{F}_{3}\right)$. The cross faults are abundant and dissect the district into a set of northerly trending fault blocks. $F_{3}$ folds are scattered unevenly across the district, but are locally coincident with the cross faults, and both are attributed to a second main deformation phase.

A previously unrecognized $S_{1}$ foliation occurs throughout the district. This foliation is commonly parallel to bedding and comprises a strong crenulate stylolitic foliation in pumiceous rocks (Fig. 9G, H), a pervasive mica foliation in chlorite- and sericite-altered rocks, and a weak, spaced foliation in some lavas and intrusions. In pumiceous rocks the $S_{1}$ foliation can be misinterpreted as a syndepositional volcanic welding fabric. The stylolitic, bedding-parallel character and strong expression in originally incompetent pumiceous and phyllosilicate-rich rocks suggest that the $S_{1}$ foliation is in part a diagenetic compaction fabric (cf. Branney and Sparks, 1990; McPhie et al., 1993). However, the local occurrence of the foliation in competant lavas and intrusions indicates that it is also an early tectonic fabric. No folds of the same generation are known.

\section{Massive Sulfide Deposits}

The main characteristics of the massive sulfide deposits are summarized below, with emphasis on the relationships between the ores and their host rocks. Detailed descriptions of some individual deposits occur in Ödman (1941), Grip (1951), Du Rietz (1953), Grip and Wirstam (1970), Svenson (1982), Trepka-Bloch (1985, 1989), Duckworth (1991), Nicholson (1993), and Bergman Weihed et al. (1996).

Similar ore types, alteration types, and geologic setting suggest that many of the massive sulfide deposits are variations on a common theme. Each deposit consists of one or more subparallel sulfide-rich ore lenses, and adjacent, low-grade, pyritic disseminated mineralization, with or without pyritic stringer vein network mineralization. The main sulfide ore lenses include massive ( $>50$ vol \% sulfide minerals), semimassive (25-50 vol \%), and impregnation $(<25 \mathrm{vol} \%)$ ores. Some deposits are dominated by massive sulfide ore (generally $>32$ wt $\% \mathrm{~S}$ in Table 1), whereas other deposits contain mainly semimassive or impregnation ore $(<20$ wt $\% \mathrm{~S}$ in Table 1). In most deposits pyritic stringer networks are restricted to the stratigraphic footwall (e.g., Näsliden, Svenson, 1982; West Maurliden, Fig. 8K); however, at Holmtjärn a stringer network also occurs in the hanging wall (Fig. 8H). The low-grade pyritic disseminated mineralization encloses 

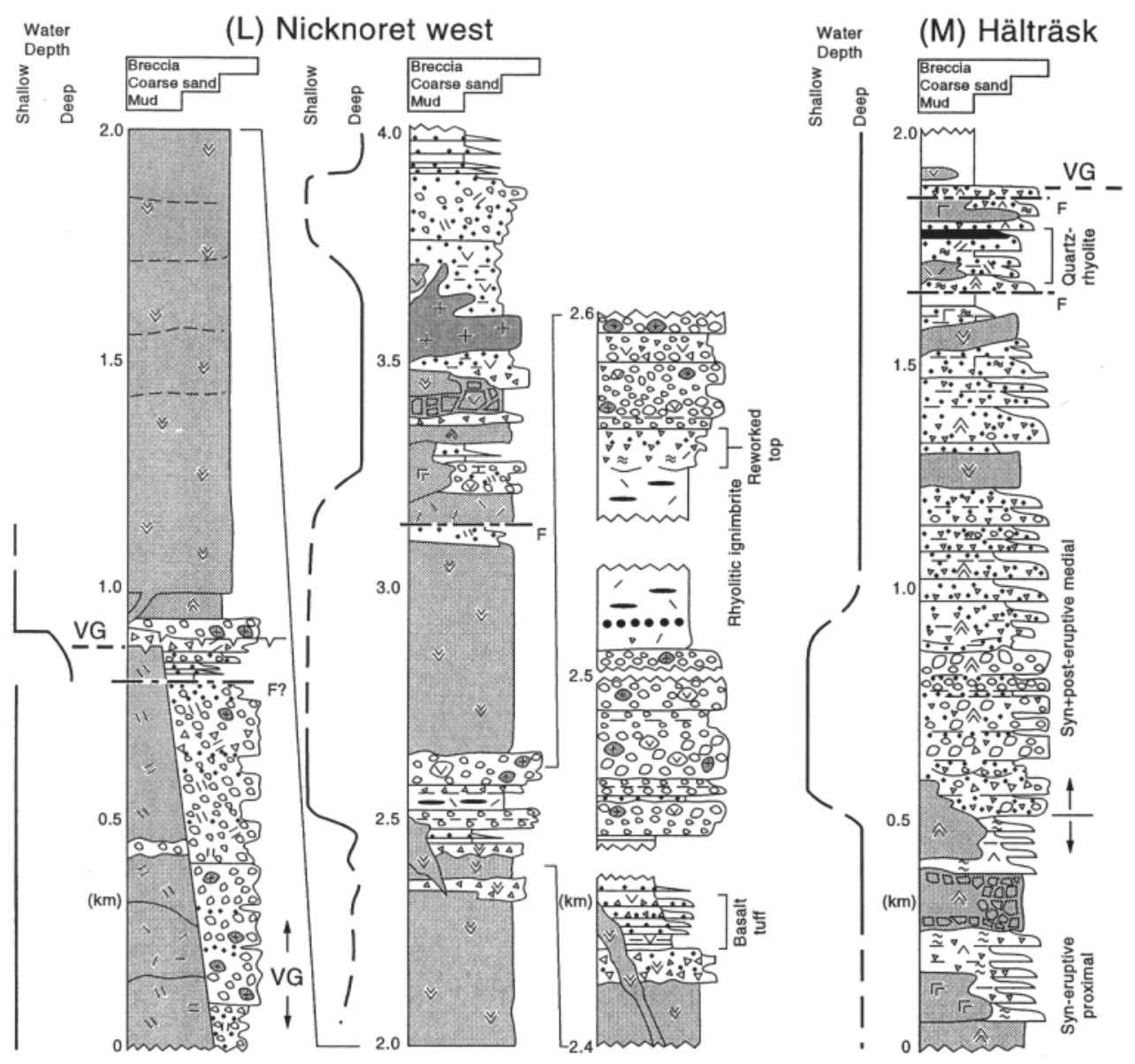

\section{Legend}

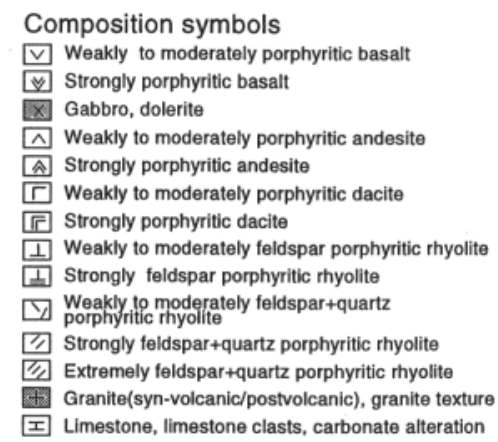

FIG. 8. (Cont.)

some deposits, but is generally more extensive in the stratigraphic footwall (e.g., Långsele, Långdal, Holmtjärn, Fig. 8).

The deposits are mainly pyritic, $\mathrm{Au}$-rich, $\mathrm{Pb}$-poor, $\mathrm{Zn}-\mathrm{Cu}-$ $\mathrm{Pb}$ deposits (Table 1, Fig. 3), but $\mathrm{Zn}$-Pb-poor $\mathrm{Cu}-\mathrm{Au}$ deposits (e.g., Boliden), and $\mathrm{Zn}-\mathrm{Pb}$-Cu deposits with moderate $\mathrm{Pb}$ contents (e.g., Renström, Långdal) also occur. High As, Sb, and $\mathrm{Hg}$ contents are common (Table 1, Fig. 3). As, Se, Bi, and andalusite formed additional economic components in the Boliden ore deposit (Grip and Wirstam, 1970). The main ore types comprise (1) pyrite with disseminations or streaks of sphalerite \pm other ore minerals, (2) complex sphaleritepyrite-galena \pm chalcopyrite, (3) fine-grained arsenopyrite \pm pyrite-chalcopyrite, and (4) chlorite with pyrite-chalcopyrite impregnation and veins. Type 3 is an unusual ore type, which formed a significant part of the Boliden deposit and smaller parts of some other deposits (e.g., Holmtjärn). Pyrrhotite is common, and sulfosalts and magnetite are accessory minerals.

All of the deposits were deformed and metamorphosed during the main orogenic phase. Strong cleavage, stretching lineation, and shearing are common, and the ores have been variably recrystallized. The deposits are now mainly steeply dipping, elliptical bodies with long axes parallel to the tectonic stretching lineation. Some deposits are tightly folded (e.g., Näsliden), partly transposed into the cleavage (e.g., Renström), or occur in faults or shear zones (e.g., Boliden). How- ever, careful drill core logging and mapping show that many of the deposits are concordant to deformed bedding surfaces, and are strata bound within particular volcanic facies or occur at particular stratigraphic boundaries (e.g., Näsliden, Renström, West Maurliden, Rävlidmyran). Furthermore, alteration assemblages, stringer vein networks, and disseminated mineralization are overprinted by the same tectonic structures $\left(\mathrm{S}_{1}, \mathrm{~S}_{2}, \mathrm{~L}_{2}, \mathrm{~F}_{2}\right)$ as the host rocks. Consequently most of the ores are interpreted as pretectonic in origin.

The massive, semimassive, and impregnation ores are all most abundant in tuffaceous volcaniclastic facies, which were probably originally very permeable. However, a few sulfide lenses occur in hydrothermal breccia zones and fault zones cutting felsic intrusions and at boundaries between intrusions (e.g., North Maurliden, Bastuheden). Stringer networks are most common in brecciated lavas and intrusions. High-grade sphalerite-galena-rich, pyrite-poor ore shoots with a breccia texture of wall-rock clasts or sulfide clasts scattered in massive sulfide matrix occur at some deposits (e.g., Renström, Långdal, Rävlidmyran). These ore shoots are attributed to mechanical remobilization of less competent, more plastically deformable (pyrite-poor), massive sulfide ore during compressional deformation.

The alteration envelopes around the deposits are mainly asymmetric with more extensive and intense alteration in the 
stratigraphic footwall. The main alteration zone is generally a quartz-sericite-pyrite zone, extending from $100 \mathrm{~m}$ to over $1 \mathrm{~km}$ along strike and up to $2 \mathrm{~km}$ into the footwall (e.g., Långdal, Långsele). An inner zone of chlorite \pm cordierite \pm andalusite-pyrite-chalcopyrite \pm sphalerite occurs along the footwall side of some ore lenses (e.g., Långsele, Rävlidmyran). Several deposits have discontinuous dolomite-calcite-chlorite-talc \pm tremolite rocks directly stratigraphically above, laterally adjacent to, and/or in among the ore lenses (Rävlidmyran, Rävliden, Rakkejaur, Renström, Långdal, Näsliden, Hälträsk). These were previously regarded as limestone sediments and exhalites; however, we suggest that only a few of the carbonate units formed on the sea floor (Näsliden, Svenson, 1982; part of the Rävlidmyran occurrences). Strong spatial association with mineralization, irregular geometry, spotty to blebby textures, and in some areas, a relict matrix of massive tuffaceous volcaniclastic facies suggest that most of the carbonate-rich units are subsea-floor alteration zones.

At a few deposits strong alteration extends well into the hanging wall. For example, at Holmtjärn the envelope of strong, pyritic, quartz-sericite alteration extends more than $150 \mathrm{~m}$ into the hanging wall. The Boliden massive sulfide lenses are subvertical and occur within a subvertical, sheared, narrow, alteration envelope, which expands out into the footwall and hanging wall at deeper levels. Pyritic quartz-sericite alteration is concentrated in the footwall. However, a system of sulfide-poor alteration zones, with an inner sericite-quartzandalusite-corundum high alumina zone and an outer chloritic shell straddles the footwall and hanging wall (Nilsson, 1968; Bergman Weihed et al., 1996).

\section{Volcanic and Sedimentary Facies Analysis Alteration, deformation, and metamorphic overprints}

Volcanological and facies interpretations were possible in most areas, except those with poor exposure and no drill core, some areas of intense hydrothermal alteration, shear zones, and areas where amphibolite facies metamorphism is superimposed on strong hydrothermal alteration.

The heterogeneous cleavage $\left(S_{2}\right)$ and strong stretching lineation $\left(\mathrm{L}_{2}\right)$ have resulted in variable, but mainly strong, modification of primary textures. The textural effects of cleavage and lineation were assessed before interpretation of primary textures by observing textures on outcrop surfaces both perpendicular and parallel to the lineation and cleavage. These surfaces show the minimum and maximum textural effect of the deformation respectively. Drill cores were routinely rotated for the same purpose, and thin sections and polished rock slices were cut perpendicular to the lineation in order to study the least deformed textures. We conclude that many preferred orientation fabrics in the rocks result from cleavage and lineation. Commonly, clasts and phenocrysts have been stretched into aligned ellipsoids, rods, and streaks. This is especially the case for feldspar phenocrysts, clasts, and patches that were altered to mechanically weak sericite-, chlorite-, or carbonate-rich compositions prior to deformation. Consequently, many volcanic rocks in the district, including many originally homogeneous intrusions and lavas, have streaky, patchy, pseudotuffaceous textures (cf. Allen, 1988). We interpret shallow porphyritic intrusions to be much more abundant than was recognized in previous studies.
Despite the $S_{1}, S_{2}$, and $L_{2}$ fabrics, many of the pumiceous rocks preserve relics of fibrous nonwelded pumice texture, similar to the textures documented by Allen $(1990,1993)$ and McPhie et al. (1993) in other massive sulfide districts. This and the evidence that the $S_{1}$ foliation is a combination of diagenetic compaction fabric and early tectonic fabric rather than a welding foliation indicate that the vast majority of pumiceous volcaniclastic rocks in the district are nonwelded rocks. The only welded pyroclastic rock confirmed in the Skellefte and Vargfors Groups is a fine-grained, originally vitric, mass flow unit (ignimbrite) in the Vargfors Group (Fig. $8 \mathrm{~L}$ ), which has a perlitic matrix texture and a prominent lithophysal zone. We regard all other foliated volcaniclastic rocks in the Skellefte and Vargfors Groups as nonwelded, until diagnostic evidence for both welding and clastic mass flow or fallout emplacement have been documented. Diagnostic evidence for welding in clastic rocks, includes perlitic or spherulitic matrix texture, pretectonic plastically compacted and annealed glass shards in the matrix, lithophysae, or well-defined columnar cooling joints (Cas and Wright, 1987, 1991; McPhie et al., 1993). However, these textures can also occur in lavas and shallow intrusions, and therefore, bed forms characteristic of clastic mass flow or fall-out deposition must also be documented in order to conclude a welded pyroclastic origin.

All volcanic rocks in the Skellefte district have also suffered various combinations of diagenetic alteration, hydrothermal alteration, metamorphic changes in mineral assemblages and grain size, and metasomatism. The effects on primary textures are extensive and variable and cannot be described here in detail. Weak to moderate diagenetic and hydrothermal alteration has commonly enhanced primary textures by accentuating compositional and textural contrasts between different clast types, between clasts and matrix, and between fractures and unfractured rock. For example, in weakly to moderately quartz-sericite-altered rocks, delicate nonwelded fibrous tube-pumice clasts, and fine arcuate perlitic fracture networks may be observed routinely on slightly weathered outcrop surfaces with the aid of a hand lens. Furthermore, in weakly to moderately altered rocks, different primary textures produce different weathered outcrop surfaces. The nonwelded pumiceous rocks commonly weather to finely knobbly, crenulate surfaces, whereas the coherent intrusions and lavas tend to have massive smooth, more homogeneous surfaces (Fig. 9). In areas of strong alteration, many primary textures are faint or obliterated, and persistence during the field work and drill core logging was required to find local relict primary textures.

\section{Main volcanic and sedimentary facies in the Skellefte district}

In Table 2 we identify 26 main volcanic, sedimentary, and intrusive facies in the Skellefte district, arrange them into seven broad groups and summarize their characteristics. The distribution, associations, and interrelationships of facies are summarized in the maps of Figures 5,6, and 7, and the stratigraphic facies columns in Figure 8. We use the term "facies" for a distinct body of rock or association of rocks that can be defined and distinguished from others by a set of distinctive characteristics that include composition, texture, volcanic or sedimentary structures and bedforms, pretectonic 

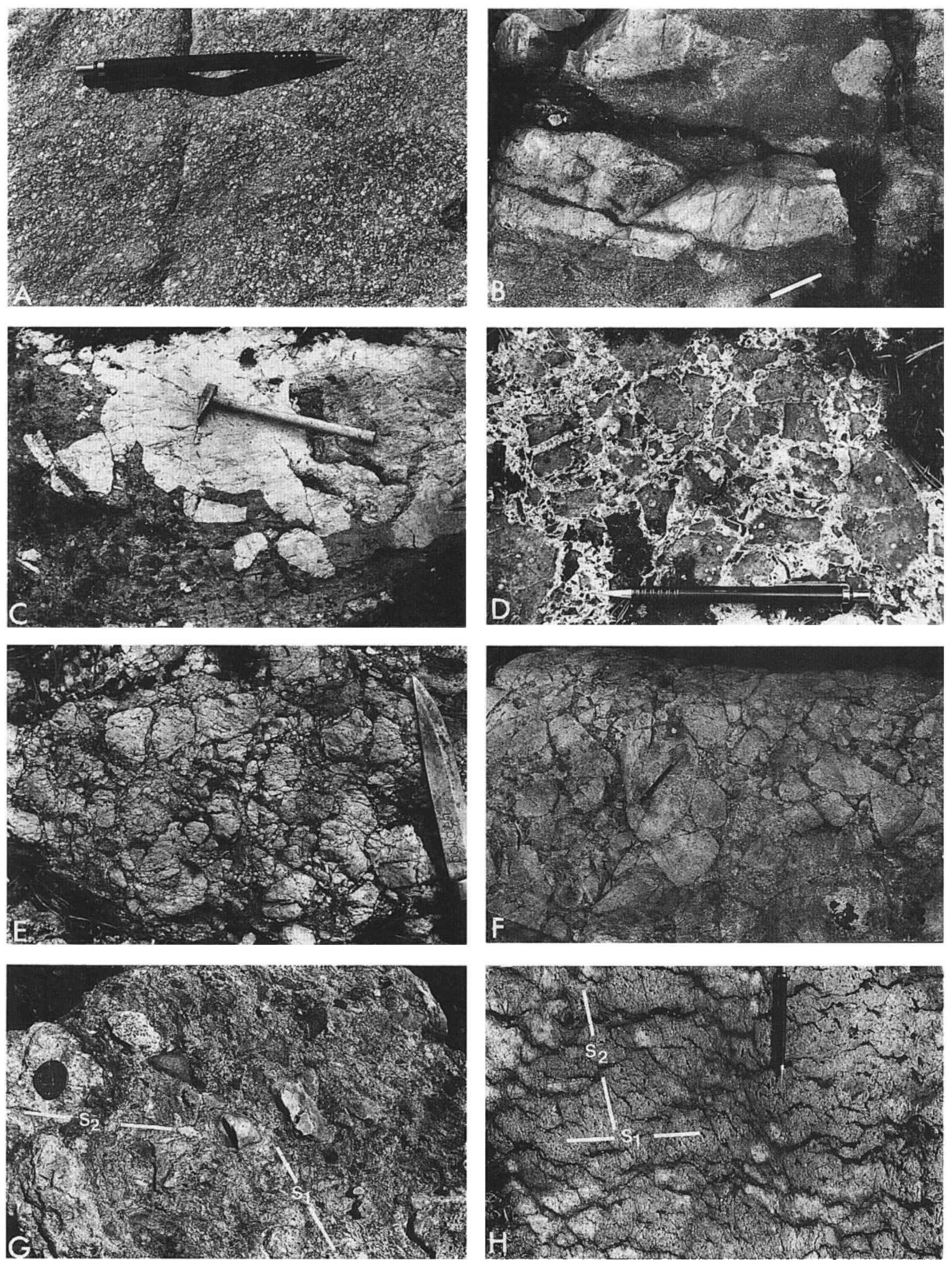

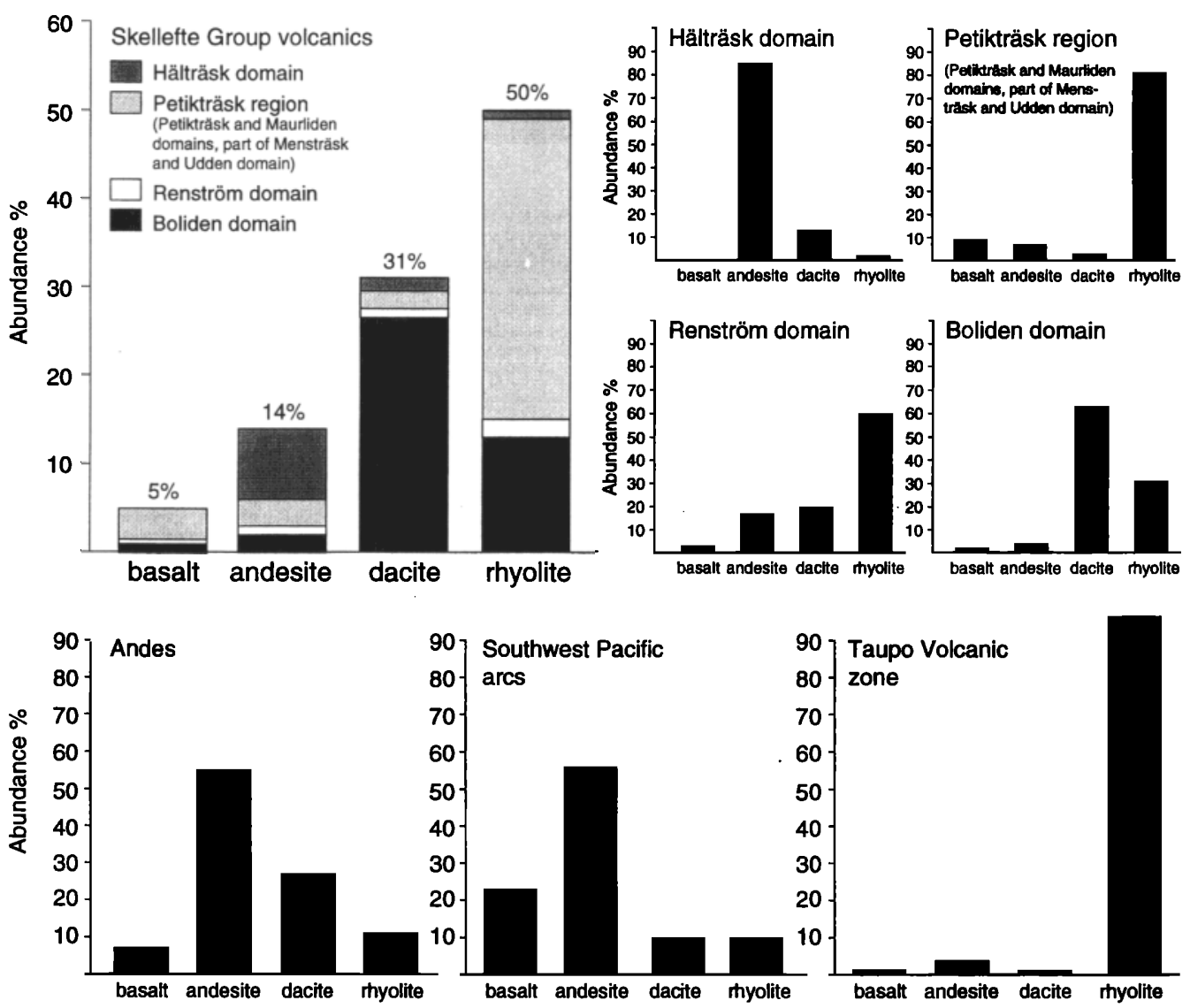

FIG. 10. Relative abundance of basalt, andesite, dacite, and rhyolite for the Skellefte Group volcanics, and comparison with the Andes and Southwest Pacific arcs (Ewart, 1982) and the Taupo volcanic zone, New Zealand (Cole, 1979, 1984; Wilson et al., 1984). Abundance percent is area (of basalt, andesite, dacite, or rhyolite) expressed as percentage of the total area of Skellefte Group volcanics in the study area. In the average for the four main areas (upper left diagram), results from each area are weighted in proportion to the size of the area so that a unit area of volcanic rock has the same significance wherever it occurs.

contact relationships, and geometry. An example and an estimate of relative abundance are provided for each facies in Table 2. For brevity, facies that differ in mineralogical and chemical composition but not other facies characteristics are combined under the same facies category in Table 2 . However, several facies were routinely mapped and subdivided to a further two orders of detail. For example, facies 1 has a second-order subdivision into rhyolite, dacite, andesite, and basalt varieties, and a third-order subdivision according to the types (quartz, feldspar, hornblende, pyroxene), abundance, relative proportions (e.g., ratio of feldspar to quartz abundance), and size of phenocrysts or crystals. This method of subdivision enabled identification of individual emplacement units of each facies type and is valid because the types and relative proportions of crystals are generally constant throughout individual emplacement units, even though the total abundance and size of the crystals may vary (for example, from the base to top of a normal-graded mass flow unit). This third-order subdivision is only invalid for compositionally zoned emplacement units (some large pyroclastic flow units, large intrusions), which are not known in the Skellefte and Vargfors Groups.

We found it most useful to define facies of transported clastic debris differently from facies of intrusions and lavas. For rocks comprising transported clastic debris, individual facies were designed to correspond to the entire stratigraphic

FIG. 9. Photographs of some main Skellefte Group volcanic facies. A. Feldspar porphyritic dacitic plutonic porphyry (facies 2, Table 2), Gillervatsbodliden, Boliden domain. B. Corroded inclusions of moderately porphyritic dacite (white) within a dacitic plutonic porphyry matrix (facies 5), Gillervatsbodliden, Boliden domain. C. Weakly brecciated intrusive margin of moderately porphyritic rhyolite (facies 1), emplaced into andesitic volcaniclastic rocks, Stor-Rörmyran, Petikträsk domain. D. Moderately amygdaloidal, andesitic, in situ hyaloclastite breccia (facies 7), Mörttjärnen, Petikträsk domain. E. In situ, lithic, hydrothermal breccia (facies 6) in intrusive rhyolite porphyry, Holmtjärn, Petikträsk domain. F. Monomict andesitic breccia-conglomerate (facies 11), Hälträsk domain. G. Lithic-rich basal part of a normal-graded dacitic pumice breccia (facies 15), Blylodtorpet, Boliden domain. H. Pumice-rich upper part of a normal-graded dacitic pumice breccia, with distinct fiamme and $S_{1}$ foliation from diagenetic compaction of large altered pumice clasts (facies 15), Kälberget, Boliden domain. 

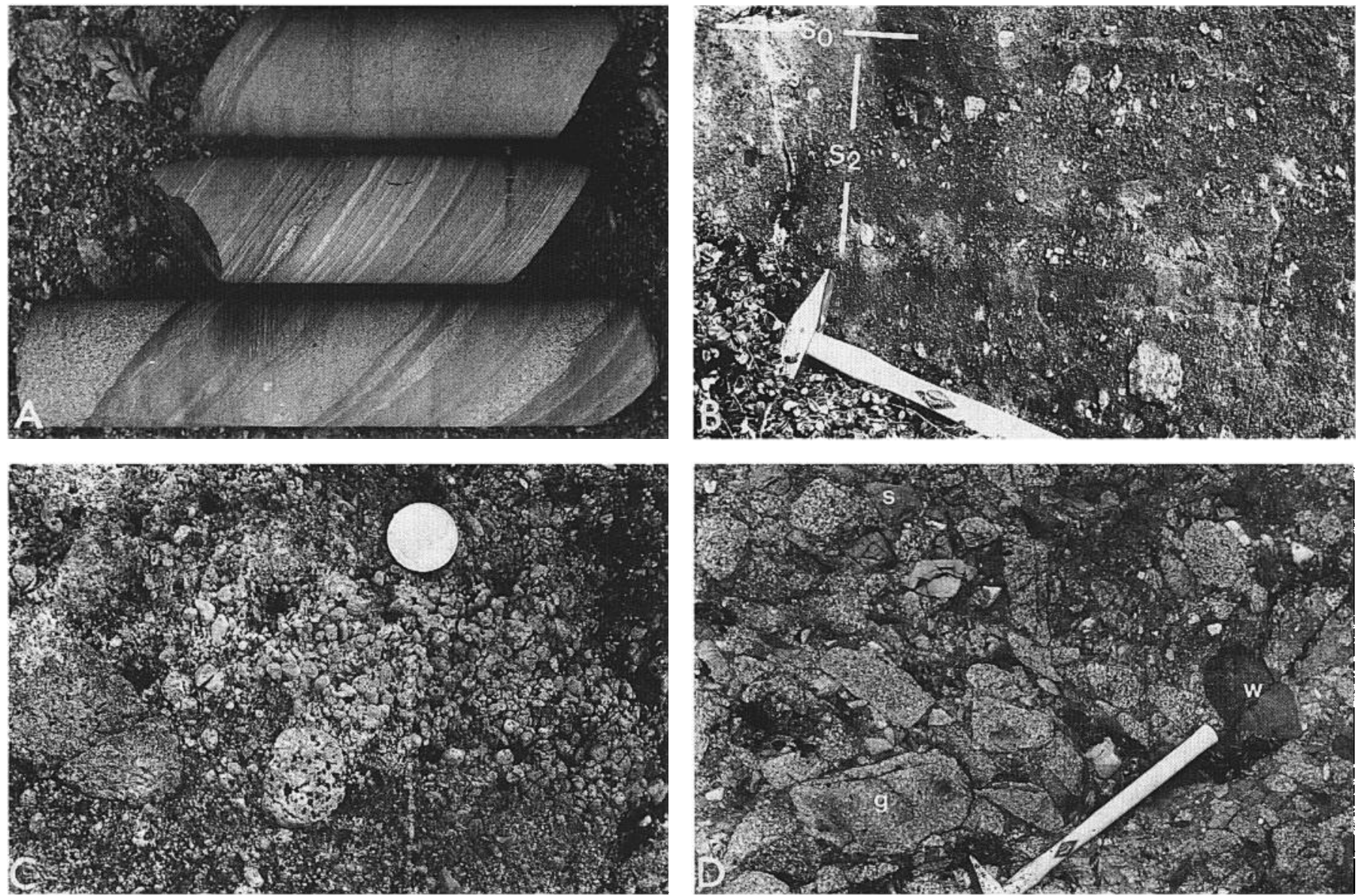

Fici. 11. Photographs of some Vargfors Group sedimentary facies. A. Dark gray mudstone and thin sandstone turbidites (facies 25), Elvaberg Formation, Boliden domain. B. Stratified polvmict rhyolitic crystal-lithic gravelly sandstone with lime matrix (facies 21), Mensträsk conglomerate, Skellefte River, Maurliden domain. C. Monomict rhyolitic pebble conglomerate (facies 11), Mensträsk conglomerate, Stenkärret, Mensträsk domain. D. Polvmict granite conglomerate (facies 24) with abunclant granite cobbles ( $\mathrm{g}$ ), common subangular clasts of locally derived Skellefte Group volcanics ( $\mathrm{s}$ ), and minor welded ignimbrite probably from Arvidsjaur volcanics (w), Abborrtjärn conglomerate, Sörträsket, Petikträsk domain.

thickness of a single emplacement unit, or to a succession of similar whole emplacement units. For example, facies 15 (Table 2) comprises one or more normal-graded beds, each mainly 10 to $50 \mathrm{~m}$ thick (rarely up to $300 \mathrm{~m}$ thick), and each with a lithic and crystal-rich base, a middle section of pumice breccia, and a normal-graded top of vitric sandstone and siltstone. For rocks related to intrusions and lavas, individual facies correspond to the various different textural components of the body, such as the coherent core, porphyry-matrix breccia (intrusion breccia), in situ hvaloclastite, sediment-matrix (intrusive) hyaloclastite, and stratified (resedimented) hyaloclastite. For these rocks individual facies result from different processes and environments in the emplacement of one unit. A single emplacement unit is defined by the facies association and bounding contact.

Timing of emplacement is divided into syneruptive and posteruptive in Table 2 . The purpose of this subdivision is to identify associations of facies and stratigraphic horizons that represent major eruptive events. The term "syneruptive" encompasses all units that were emplaced during, or continuous with, the eruption from which they were derived, regardless of depositional environment and the processes and history of transport and deposition. These units include primary pyroclastic deposits and syneruptive, resedimented deposits in the terminology of McPhie et al. (1993). Syneruptive units are generally characterized by texturally juvenile, monomict composition and evidence of rapid emplacement. Posteruptive units display textural, compositional, or other evidence that they were reworked and emplaced after cessation of the eruption from which they were derived. This evidence includes various combinations of rounded clasts, polymict composition, vitric-poor crystal \pm lithic-rich composition, and occurrence in facies associations that indicate deposition over a long time period, such as alternation with mudstones.

The most abundant facies in the Skellefte district are (1) normal-graded pumiceous breccias (facies 15, Table 2; Fig. $9 \mathrm{G}-\mathrm{H}$ ), which are interpreted as syneruptive subaqueous mass flow units of pyroclastic debris, (2) coherent porphyritic intrusions and lavas (facies 1; Fig. 9A-C), (3) mudstone and sandstone turbidites (facies 25; Fig. 11A), and (4) in situ hyaloclastite breccia (facies 7; Fig. 9D), which occurs at the margins of many intrusions and lavas. These four facies are 
abundant throughout the district, whereas the other 22 facies are either scattered in subordinate abundance throughout the district or are locally abundant in particular domains (Figs. 5-8).

\section{Fragmentation and eruption processes}

In order of decreasing abundance, clastic fragmentation processes in the Skellefte district were mainly pyroclastic fragmentation, epiclastic erosion, quench fragmentation, hydrothermal brecciation and intrusive brecciation (Table 2). The facies derived from pyroclastic fragmentation are characterized by abundant pumice or scoria, glass shards and/or liberated crystal grains, and subordinate lithic clasts of poorly vesicular lavas and intrusions. Lithic-dominated pyroclastic units are rare. The lateral extent and volume of most pyroclastic units are not possible to determine accurately because of poor exposure. However, the average thickness of 10 to 50 $\mathrm{m}$, maximum thickness of $300 \mathrm{~m}$, and lateral extent of at least several kilometers for individual emplacement units of the most abundant syneruptive facies (facies 15) suggest that pyroclastic eruptions were commonly at least 1 to $10 \mathrm{~km}^{3}$ in volume. These clast types and volumes indicate that pyroclastic fragmentation was magmatic and/or phreatomagmatic, and the main pyroclastic eruption styles probably involved moderate to large eruption columns and pyroclastic flows.

Facies derived from epiclastic erosion mainly comprise breccias and conglomerates composed of clasts of lavas and intrusions (Table 2). The clast types in particular depositional units indicate which strata and areas were being uplifted and eroded at that time. In several monomict to weakly polymict breccia-conglomerates (facies 11) the clasts are subpolygonal blocks with subrounded to rounded corners, which indicates that the source rock was fragmented or intensely jointed prior to erosion. These breccia-conglomerates are not strictly epiclastic. They are attributed to collapse and subsequent reworking of jointed lava dome edifices, fault scarps of lava, and uplifted hyaloclastite piles. A spectacular example occurs in the Hälträsk succession where a 400 -m-thick pile of breccia-conglomerate is composed entirely of the same andesite clast type $(0.5-0.9 \mathrm{~km}$; Figs. 8 and $9 \mathrm{~F})$. This pile is attributed to collapse of a large andesite dome.

Volcanic breccias composed of angular, poorly vesicular blocks of lavas or intrusions are common in the Skellefte district and were previously regarded as mainly proximal (near vent) pyroclastic breccias. We interpret these breccias as quench breccias (facies 7 and 8), hydraulic and hydrothermal breccias (facies 6), and intrusion breccias (facies 5). Most of the quench breccias are hyaloclastite and have characteristics in common with the hydrothermal and hydraulic breccias, including mainly clast-supported organization, pervasive in situ (jigsaw-fit) breccia texture or local gradations into in situ breccia, blocky clasts with curviplanar margins, and common occurrence in shallow intrusions and lavas (Fig. 9D, E). Consequently, these two breccia types may be difficult to distinguish in a single outcrop or drill core. Criteria used to distinguish the hyaloclastite breccias include restriction to the margins of shallow intrusions and lavas, facies association with sediment-matrix hyaloclastite breccia (peperite, facies 8 ) toward the margin of the intrusion or lava and more crystalline (e.g., spherulitic) coherent facies (facies 1) toward the center of the body, monomict clast assemblage, relict glassy textures such as perlitic fractures within the clasts, and dominance of broad arcuate-shaped clast margins and fractures (Fig. 9D). Criteria that appear useful in the Skellefte district to distinguish hydrothermal breccias include occurrence in relatively crystalline as well as originally glassy rocks, subplanar or irregular crenulate fractures and clast margins more abundant than broad arcuate shapes, local or extensive areas of clasts with subrounded corners, local sheeted to branching fracture sets, fractures or veins crosscutting earlier formed fractures or veins, local areas with two or three clast compositions, local veins of matrix-supported, slurry-textured transported breccia, and commonly strong alteration in the fractures and breccia matrix (Fig. 9E). Hydrothermal breccias are especially common in the Maurliden domain and near Holmtjärn. The breccias are attributed to intense hydraulic fracture propagation in overpressured subregional hydrothermal systems that are spatially associated with felsic intrusion and lava complexes, which may also be related to sulfide mineralization.

An interesting variation of quench breccia is the subaqueous, basaltic fire fountain breccia-agglomerate facies (facies 10, Table 2) found at Granbergsliden (Holmtjärn area, Petikträsk domain, Fig. $8 \mathrm{H}$ ) and in two parts of the Renström domain (Fig. 8E, F). These breccias comprise fluidal bombs set in a matrix of the quench-fragmented, spalled bomb rinds. The eruptions are interpreted to have been the subaqueous equivalent of Hawaiian fire fountain eruptions, in which basalt magma blobs (bombs) were jetted up above the sea floor in magma fountains. Quench fragmentation of bomb margins occurred as they fell to the sea floor. The well-exposed breccia-agglomerate units at Granbergsliden are intercalated with basalt pillow lava and andesite sheet flows (Fig. $8 \mathrm{H}$ ) in a mafic volcano at least $400 \mathrm{~m}$ thick and $3 \mathrm{~km}$ wide. The fire fountain breccia-agglomerate facies is attributed to the eruption of fluidal basaltic magma at high discharge rates from fissure vents. During periods of low discharge rate, magma fountains did not form and the basaltic magma erupted as pillow lava.

The intrusion breccias comprise brecciated and variably dismembered areas of one coherent porphyritic volcanic rock set in a matrix of another more strongly porphyritic coherent volcanic rock (Fig. 9B). These breccias have areas of in situ breccia texture and the clasts have irregular subrounded corroded margins. The breccias are attributed to intrusion of coarse subvolcanic porphyries into their roof rocks. Initial fragmentation was hydraulic(?) brecciation of the roof rocks adjacent to the intrusion. This was followed by intrusion of porphyry into the brecciated roof rocks and partial collapse and assimilation of the brecciated roof rocks into the porphyry.

\section{Emplacement processes}

Four main processes account for the emplacement of most rocks. Normal-graded beds with sharp bases and gradational tops, occurrence in thick successions of similar beds, and common association with dark mudstones, together indicate that most of the volcaniclastic and sedimentary facies were emplaced by gravity-driven, subaqueous clastic mass flow processes. Depending on the volume and grain size of the clastic debris being transported, the mass flows varied from silty- 


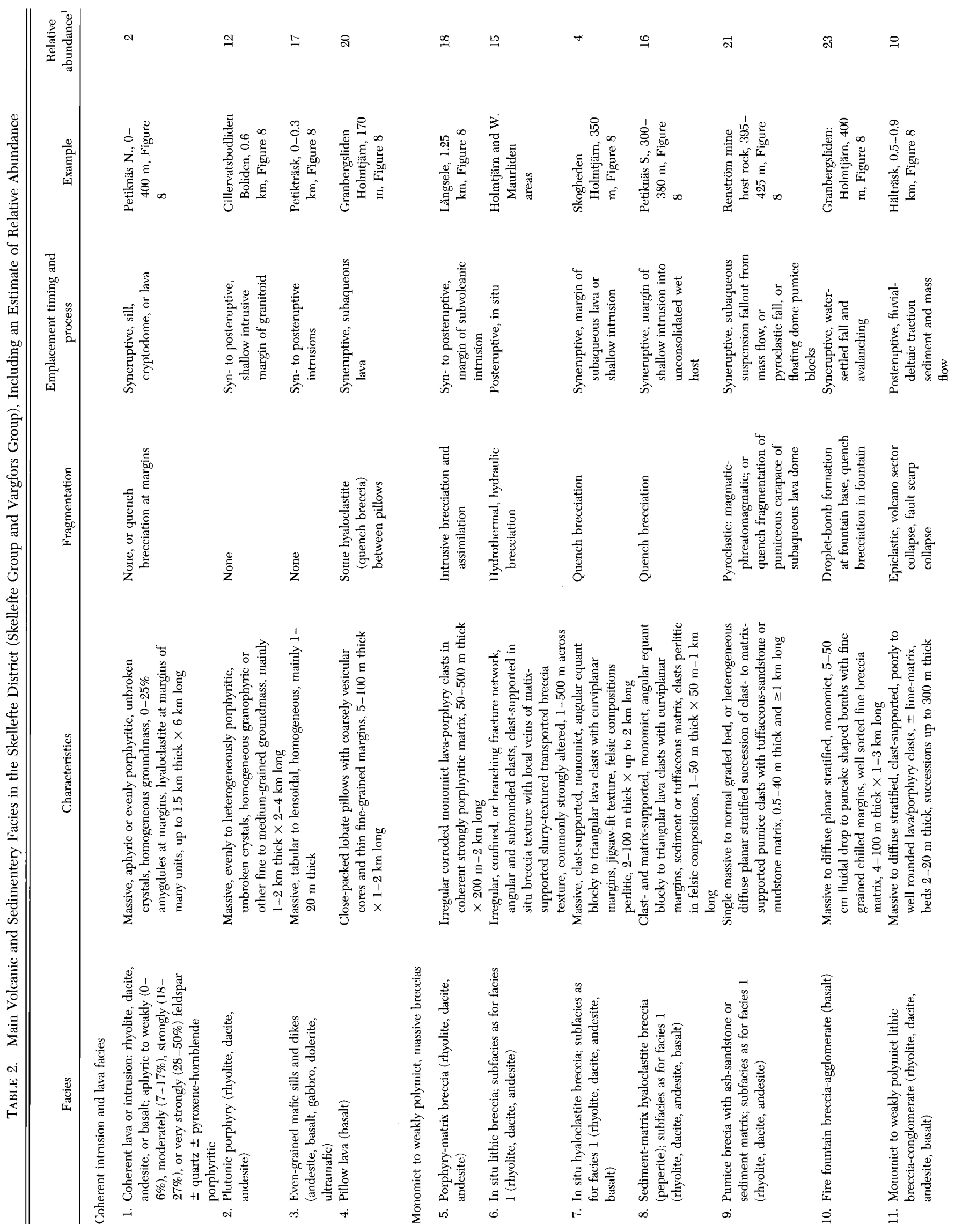


芩 9

เัง

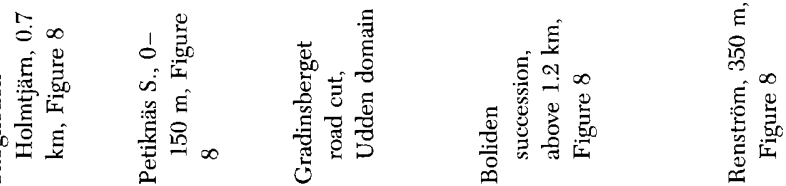

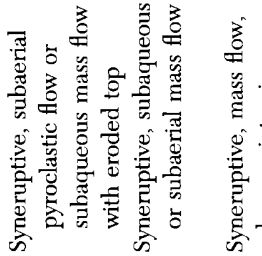

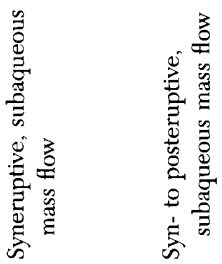

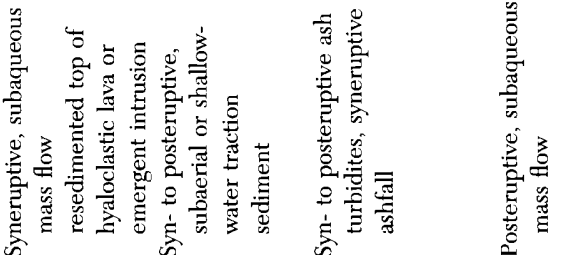

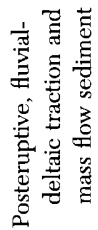
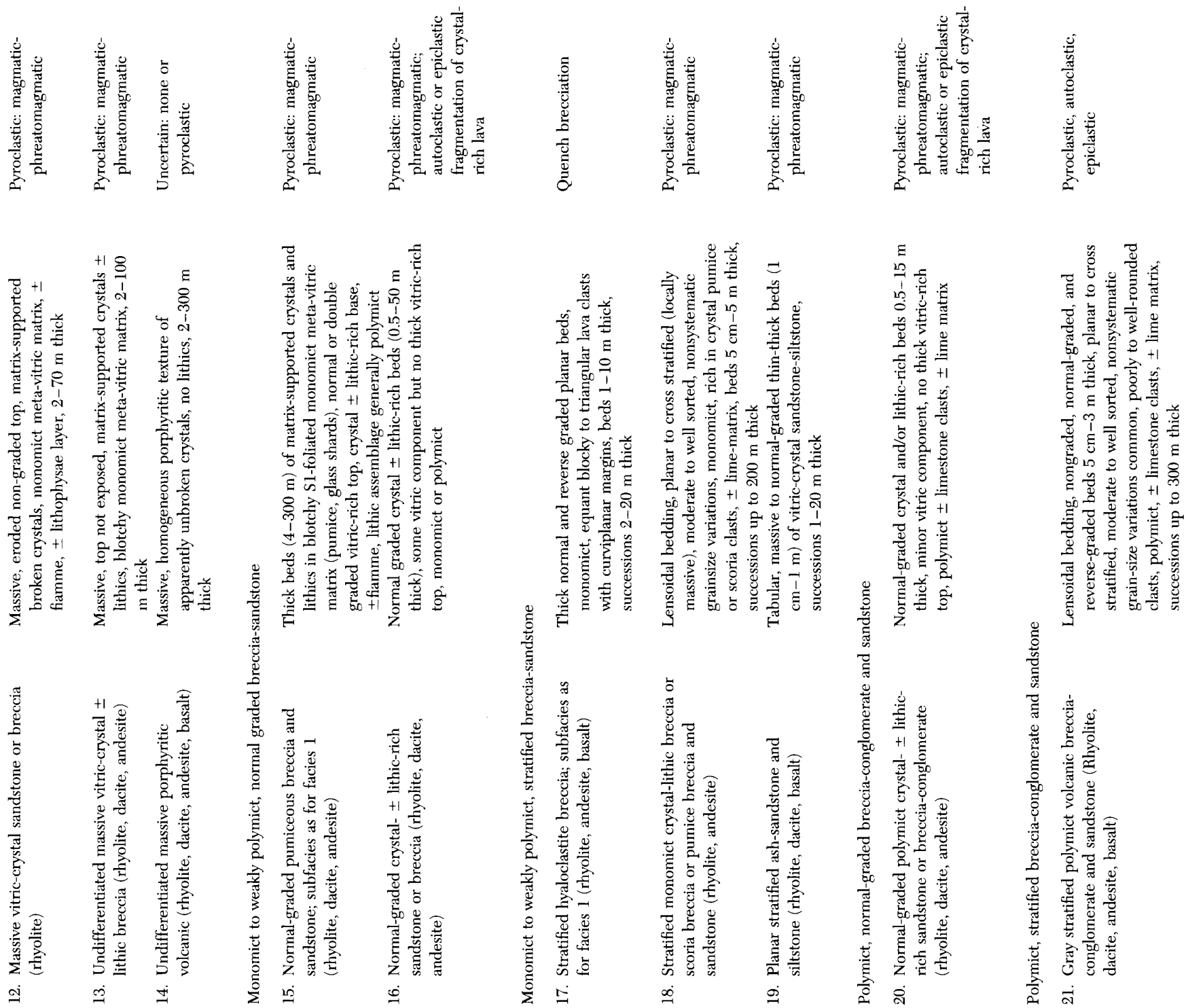


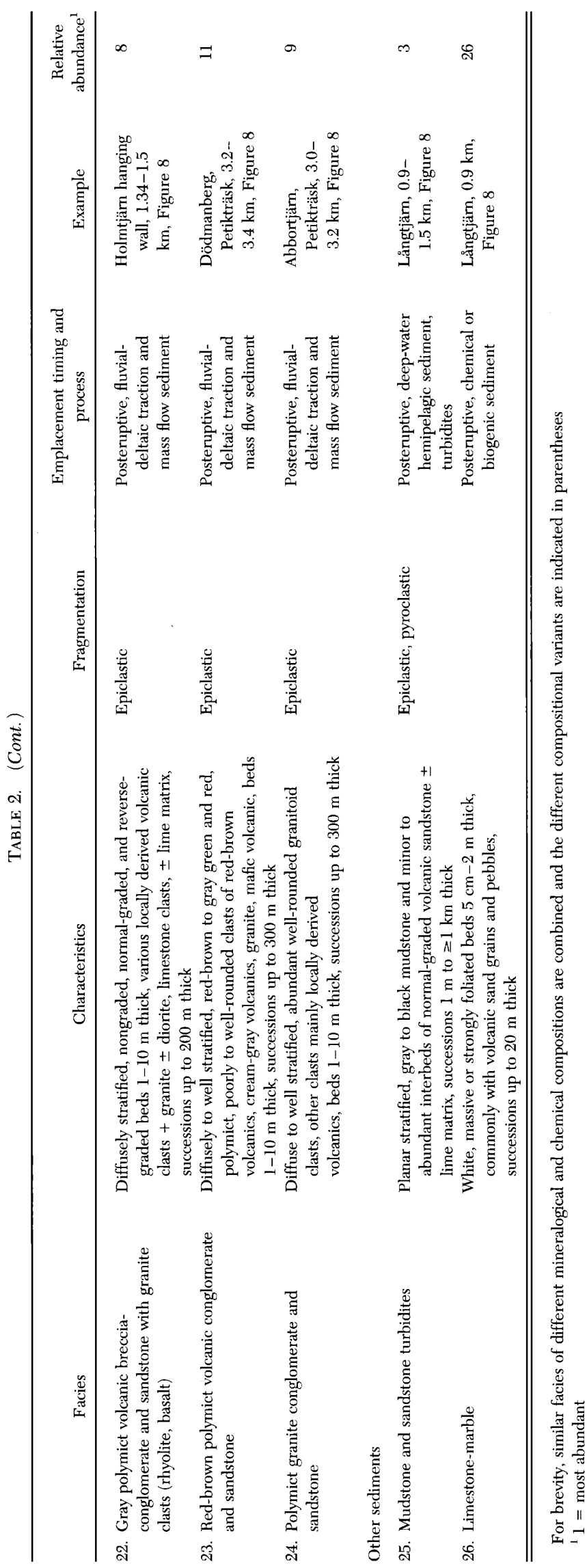

gravelly turbidity current flows (facies 16, 17, 19, 20, 25) to sandy-gravelly high concentration, megaturbidity current flows (facies 15, 16, 20).

The second most common emplacement process was intrusive emplacement of the coherent volcanic rocks and their associated clastic facies (facies $1-3,5,7,8$ ). Contact relationships at the top of lavalike units are the main diagnostic evidence for extrusive versus intrusive emplacment (Allen, 1992), and most upper contacts that are exposed in outcrop and drill core in the Skellefte district show evidence of intrusion. The evidence includes (1) sediment-matrix hyaloclastite (peperite, facies 8) along the upper contact, formed by invasion of hyaloclastite into wet, unconsolidated strata, (2) fingerlike veins and apophyses of coherent to hyaloclastic volcanic rock into overlying strata, or (3) porphyrymatrix (intrusive) breccia (facies 5) near the upper contact, and (4) the paucity of stratified (resedimented) hyaloclastite at the top and margins of lavalike units. These features indicate that most coherent volcanic rocks and their associated marginal clastic facies intruded into the volcanic succession and only locally breached the sedimentation surface. Subordinate occurrences of resedimented hyaloclastite (facies 17), eroded reworked tops of lavas, and pillow lava without sediment matrix (facies 4) indicate that extrusive lava emplacement occurred locally.

The third main emplacement process was subaerial to shallowwater mass flow emplacement of many of the breccia-conglomerate units (parts of facies 11, 21-24). Evidence that many units of these facies were emplaced by subaerial to shallow-water mass flow processes include (1) thick, massive to reverse-graded bedforms without normal-graded tops, (2) local interbedded cross stratified and multiply scoured sediments, which indicate a subaerial to shallow-water environment, (3) absence of interbedded mudstone and sandstone turbidite facies, and (4) poor stratification, which is consistent with rapid emplacement. Other details and facies associations of the units indicate that the mass flow processes ranged from fluvial, flood-driven mass flow to shallowwater deltaic mass flow sedimentation.

The fourth main emplacement process was subaerial to shallow-water traction sedimentation of some units of breccia, breccia-conglomerate, and sandstone (facies 18 and parts of facies 21-24). Traction sedimentation in these facies is indicated by abundant traction current structures and bedforms, including beds with abundant internal scours, cross bedding, lensoidal bar forms, nonsystematic vertical grain-size variations, and rapid lateral grain-size variation along the same bed (Figs. 11B and 12). These structures and bedforms contrast with the simple normal-graded and laterally continuous bedforms of the subaqueous mass flow facies described above. Evidence that traction sedimentation was mainly restricted to subaerial and shallow-water depositional environments is described below.

Other minor emplacement processes include suspension sedimentation of subaqueous pyroclastic fallout (facies 9,10 , and some units of facies 19), subaerial gas-supported pyroclastic flow (facies 12), and chemical or biogenic sedimentation of limestone (facies 26).

\section{Timing of emplacement}

Juvenile monomict composition and thick mass emplacement bedforms or structures indicate that most facies in the Skellefte district were emplaced rapidly during or directly 
after volcanic eruptions and intrusive events. In particular, all facies emplaced in below-storm-wave base subaqueous environments (see below), except for the mudstone and turbidite facies (facies 25) and some units of subaqueous volcaniclastic mass flows (facies 16, 19, and 20), are syneruptive deposits. In contrast, most of the facies emplaced in subaerial to shallow-water environments (see below) are posteruptive deposits. We attribute this difference to the paucity of processes capable of eroding or reworking strata in below-stormwave base environments and the dominance of these processes in subaerial to shallow-water environments.

\section{Facies associations, facies successions, and depositional} environments

Few single facies are diagnostic of depositional environment. More reliable and detailed interpretations of depositional environment can be made from the characteristic associations or successions in which facies occur (Cas and Wright, 1987). The facies associations and successions that are characteristic of different parts of the Skellefte district are shown in Figure 8. The most common group of facies associations comprises successions of thick bedded, normal-graded, volcaniclastic subaqueous mass flow facies with local to abundant interbedded gray-black mudstone and sandstone turbidite facies. This group of facies associations can be subdivided into associations dominated by syneruptive mass flow units (e.g., Bastuliden, Fig. 8D) or posteruptive mass flow units (e.g., top of Boliden succession, Fig. 8C), or posteruptive mudstone and sandstone turbidite facies (e.g., $0.9-1.3 \mathrm{~km}$ in the Långtjärn succession, Fig. 8J). All these associations lack evidence of abundant erosion, reworking, and traction current bedforms and are attributed to deposition in a consistently belowstorm-wave base, subaqueous depositional environment. For example, the association dominated by syneruptive mass flow units records ambient subaqueous posteruptive deposition at relatively low sedimentation rates (mudstone and sandstone turbidite facies), punctuated by rapid emplacement of large volumes of juvenile pyroclastic debris after each major pyroclastic eruption. The gravity-driven mass flows would have been channeled and ponded within topographic lows. Consequently, variations in the ratio of mudstone and sandstone turbidite facies to syneruptive mass flow facies probably reflect both variations in the frequency and volume of volcanic events and variations in sea-floor topography caused by synvolcanic faulting.

The second most abundant group of facies associations comprises various combinations of aphyric to porphyritic coherent intrusions, lavas, in situ hyaloclastite, sediment-matrix hyaloclastite, stratified hyaloclastite, porphyry matrix breccia, and in situ lithic breccia (facies 1, 2, 4-10). The common occurrence of hyaloclastite in these associations indicates that the intrusions and lavas were mainly emplaced into watersaturated strata in subaqueous environments. The nature of these environments can be resolved further into two main types according to the volcaniclastic facies associations that enclose or interfinger with the intrusions and lavas. Some of the intrusion and lava associations are completely embedded within the subaqueous mass flow-mudstone and turbidite facies associations described above, and consequently, are attributed to emplacement into moderately deep-water succes- sions in which depositional environments were consistently below storm wave base (e.g., Fig. 8F, 150-400 m). However, some contain local interbedded clastic facies with shallowwater to subaerial traction current bedforms (e.g., Fig. $8 \mathrm{H}$, $800 \mathrm{~m}-1.74 \mathrm{~km}$ ). These intrusion and lava complexes are therefore interpreted to have been locally emergent above wave base or sea level.

The matrix of the porphyry-matrix intrusive breccias (facies 5 ) is mainly coarse, crystal-rich porphyry without any marginal hyaloclastite facies. This association suggests that the very crystal-rich porphyries with porphyry-matrix breccia are subvolcanic intrusions that were emplaced in deeper, less watersaturated parts of the volcanic pile.

A third group of facies associations is that dominated by clastic facies with traction current structures and bedforms. These associations contain evidence of erosion, scours, and reworking, and lack dark mudstones and other facies that occur in the below-storm-wave base facies associations (Fig. 12). They are therefore attributed to deposition in shallowwater to subaerial environments. Their common gradational contacts with the subaqueous below-wave base associations suggest deposition in near-shore fluvial-deltaic environments.

The distribution of different depositional environments in time and space through the Skellefte and Vargfors Groups is shown by the water depth curves interpreted from the various facies associations and drawn alongside each stratigraphic column in Figure 8 , and by the distribution of depositional environments interpreted for the Boliden, Renström, and Petikträsk regions in Figure 13. These results indicate that belowwave base environments were most abundant during emplacement of the Skellefte Group and that shallow-water to subaerial environments were most abundant during emplacement of the Vargfors Group. However, despite being volumetrically subordinate, shallow-water to subaerial environments occurred in many areas of the Skellefte district during Skellefte Group volcanism and were especially common in the central part of the district. Furthermore, below-wave base environments were common during Vargfors time and were locally dominant. These results suggest alternation of shallowand deep-water environments both in time and space, in both the Skellefte and Vargfors Groups. The alternations in environment are attributed to variations in the interplay between subsidence (tectonic and volcanotectonic), accumulation of strata, and uplift due to emplacement of shallow intrusions.

\section{Environments of eruption versus deposition}

It has generally been assumed that the various volcanic rocks of the Skellefte district were erupted in the same areas and depositional environments in which they now occur. This is valid for the intrusions, lavas, and related rocks but is not valid for the subaqueous mass flow facies. The facies associations described above provide diagnostic data on the environments of deposition, but not necessarily on the environments of eruption. Considering the distribution of depositional environments demonstrated above, it is likely that a significant part of the volcaniclastic debris was derived from topographically high areas (including subaerial, shallow-water areas) and was distributed downslope into deeper water environments by subaqueous mass flow processes. The highly pumiceous 

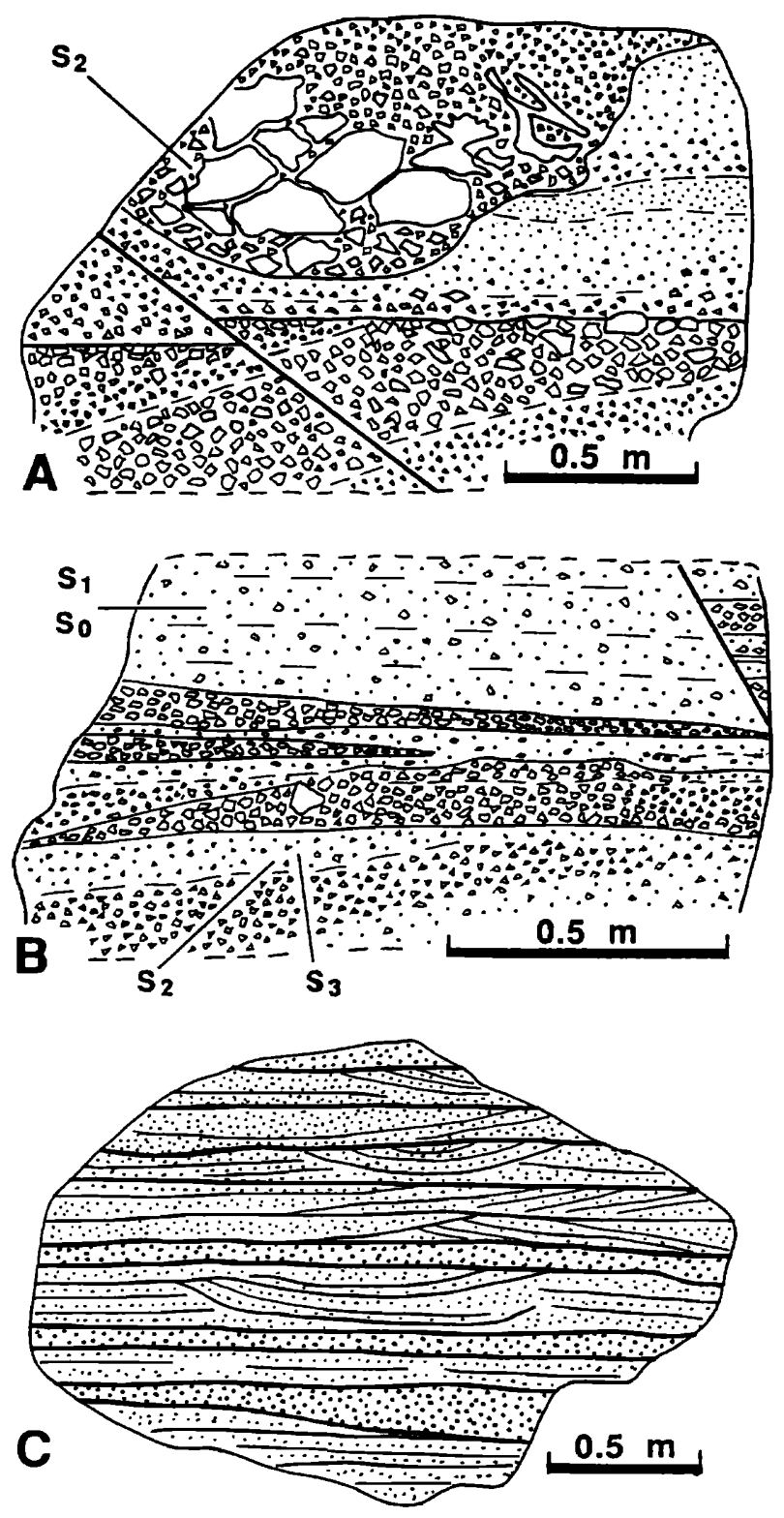

FIG. 12. Sketches of shallow-marine to fluvial bed forms in Skellefte Group volcanics. A. Red, oxidized, planar- and cross-stratified, andesitic breccia-conglomerate and sandstone (facies 21) with prominent planar erosion horizon and channel, $45 \mathrm{~m}$ stratigraphically below the Kyrkväg and Renström massive sulfide deposits. B. Stratified monomict andesitic scoria breccia and sandstone (facies 18) with lensoidal gravel bar forms, 200 to 300 $\mathrm{m}$ stratigraphically below the Petiknäs South massive sulfide deposit. C. Trough cross-stratified, andesitic crystal-rich sandstone (facies 18), Hälträsk domain, $1 \mathrm{~km}$ stratigraphically below a massive sulfide ore.

and lithic-poor character of the pyroclastic debris is consistent with, but not diagnostic of, subaerial to moderately shallowwater eruptions, in which low hydrostatic confining pressure allowed intense vesiculation. However, the subordinate volume, local distribution, and generally local provenance of epiclastic posteruptive deposits in the Skellefte Group argue against the presence of large landmasses in the region at that time. The topographic highs were most likely local intrabasinal horsts, the summits of constructional volcanoes, and the summits of volcanoes domed up by underlying intrusions. These local topographic highs may have been vent locations for some of the highly pumiceous pyroclastic debris in the district; however, tectonic or volcanotectonic subsidence following the eruptions probably returned some of these vent areas to deeper water environments again.

\section{Volcano Types and Facies Architecture}

Areas of petrographically and chemically related facies with systematic vertical and/or lateral changes in facies characteristics and facies associations are defined in this study as individual volcanoes or complexes of two or more similar volcanoes. The seven volcano types recognized and examples of each are listed in Table 3. The distribution of volcano types corresponds in a general way to the geologic domains identified by Boliden geologists. The domains represent individual volcanoes, volcanic complexes of several volcanoes of the same type, and areas with two to three interfingering volcano types. Some domains are partly defined by bounding shear zones.

Vent areas are the fundamental reference points in volcanic terranes. Therefore, the different volcano types were defined by grouping facies from all study areas into generalized proximal, medial, and distal facies associations for each volcano type. In this paper we focus on the subaqueous rhyolite cryptodome-tuff volcano type because many of the massive sulfide ores occur in those volcanoes. The characteristic proximal, medial, and distal facies associations are summarized in Table 4, and in Figure 14 these characteristic facies associations are synthesized into two schematic reconstructions of the rhyolite cryptodome-tuff volcanoes. These facies associations and reconstructions provide models that can be used to interpret in which part of the volcano any particular area lies. They also allow prediction of lateral facies changes, provide vectors toward vents, and provide a framework for interpretation of the setting of the massive sulfide ores.

\section{Subaqueous rhyolite cryptodome-tuff volcanoes}

These volcanoes form only 5 percent or less of the area of the Skellefte district but are associated with many massive sulfide deposits (Figs. 2, 13). From the many partially exposed examples of rhyolite cryptodome-tuff volcanoes, we estimate they range from 2 to $10 \mathrm{~km}$ in diameter and 250 to $1,200 \mathrm{~m}$ thick at the center. They occur in the Boliden and Petikträsk domains and are especially common in the Renström domain. They are inferred to occur in the Hälträsk and Maurliden domains (see below), and from the literature we infer that they also occur in domains not covered in this study (Udden, Rakkejaur-Näsliden). The rhyolite cryptodome-tuff volcanoes can be regarded as a subaqueous analogue of subaerial dometuff cone volcanoes (cf. Cole, 1970) and are similar in style to subaqueous rhyolitic dome-intrusion-tuff volcanoes described by Horikoshi (1969), Kokelaar et al. (1985), and Cas et al. (1990).

The subaqueous rhyolite cryptodome-tuff volcanoes in the Skellefte district are all characterized by a small to moderate volume, syneruptive, rhyolitic, pumiceous pyroclastic deposit, intruded by porphyritic rhyolite cryptodomes, sills, and dikes (Table 4). Multiple generations of rhyolite magma emplacement are typical and are indicated by different size, abundance, and proportions of quartz and feldspar phenocrysts in 

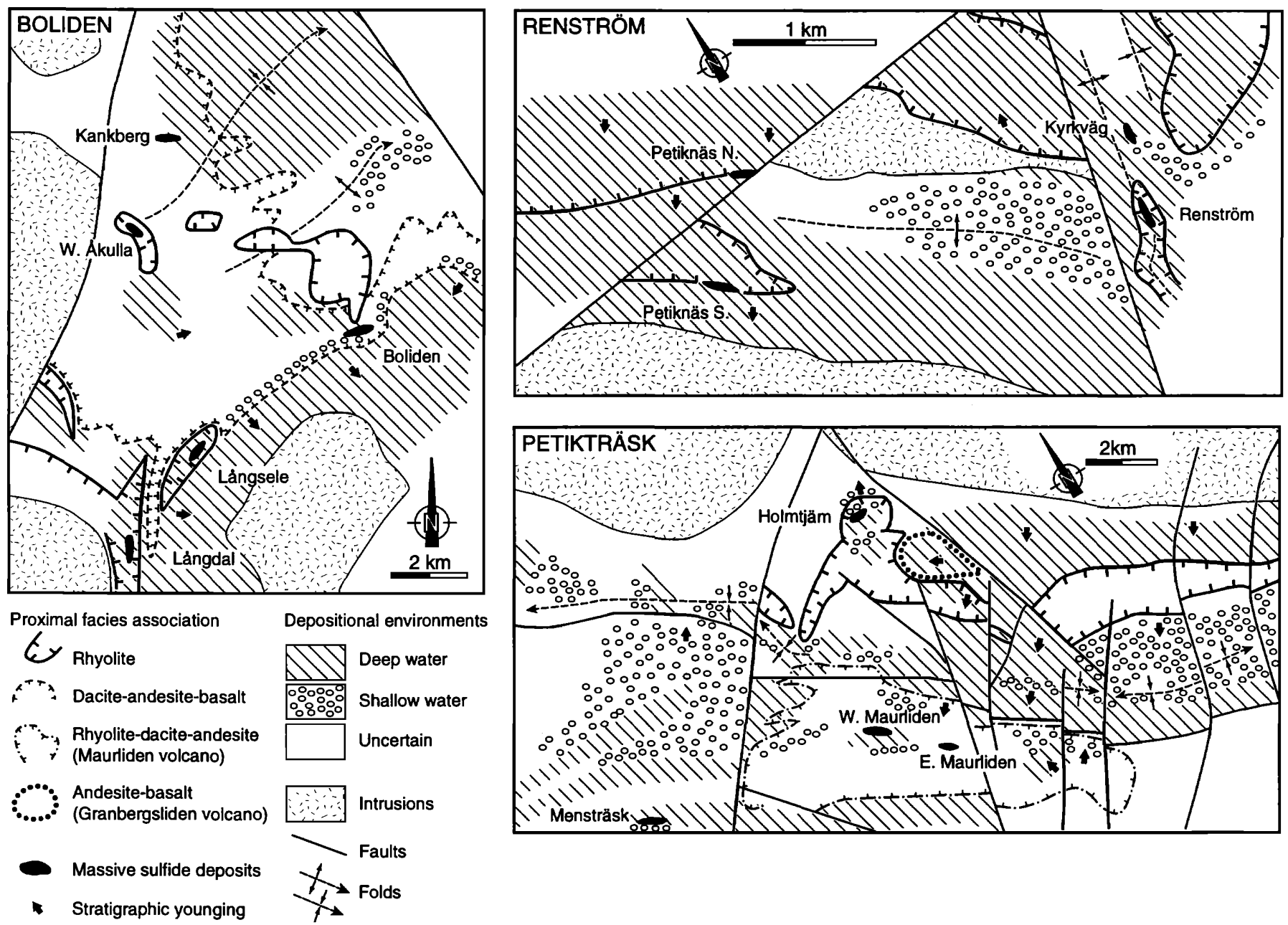

Fig. 13. Correlation of massive sulfide ores in the Boliden, Renström, and Petikträsk areas with deep- and shallowwater depositional environments, and proximal facies associations. The maps correspond to the same areas as Figures 5 , 6 , and 7 .

the various emplacement units. Large round quartz phenocrysts are common in some of the more coarsely porphyritic units. Three generations of rhyolite were observed at Petiknäs North, four generations at Petiknäs South, and at least nine generations at Holmtjärn. These volcanoes appear to be fundamentally rhyolite dome and sill complexes. An early gasrich magma batch was erupted pyroclastically to form a pumi- ceous tuff deposit. Subsequent degassed magma batches were emplaced within the tuff deposit as sills, dikes, cryptodomes, partially emergent cryptodomes, and possibly some lavas. The two models in Figure 14 cover the spectrum from cryptodome-tuff volcanoes with a small number of intrusions, to those with many intrusions. The former is similar to the situation at Petiknäs North and the latter to Holmtjärn.

Table 3. Volcano Types Recognized in the Skellefte District and Arvidsjaur Area

\begin{tabular}{|c|c|}
\hline 1. Subaqueous rhyolite cryptodome-tuff volcano & $\begin{array}{l}\text { Renström domain: Petiknäs N., Petiknäs S., Renström, } \\
\text { Viterberget, Kyrkvägamyrberget } \\
\text { Boliden domain: Långsele, Långdal?, W. Åkulla } \\
\text { Other domains: Holmtjärn, Maurliden, Hälträsk }\end{array}$ \\
\hline 2. Dacite-andesite-basalt intrusion-lava-mass flow complex & Boliden domain: L̊ngdal-Boliden-Kankberg area \\
\hline 3. Emergent marine andesite cone & Hälträsk domain \\
\hline 6. Shallow marine-terrestrial basalt lava shield and tuff cones & Vargfors Group: Gallejaur \\
\hline 7. Subaerial rhyolitic caldera & Arvidsjaur Group: Rakkur (B. Sjöblom, unpub. data), Högbränna \\
\hline
\end{tabular}


TAble 4. Proximal, Medial, and Distal Facies Associations of Rhyolite Cryptodome-Tuff Volcanoes in the Skellefte District

Proximal facies association ( = volcano center or vent area)

Multiple generations of cryptodomes, sills, and dikes \pm extrusive domes and lava lobes (facies 1)

In situ hyaloclastite breccia (facies 7 )

Sediment-matrix hyaloclastite breccia (facies 8)

Thick unit of very thick bedded, normal- to double-graded, pumiceous breccia-sandstone (facies 15)

Thick unit of heterogeneous pumice breccia and ash-sandstone (facies 9)

In situ lithic (hydrothermal) breccia (facies 6)

Synvolcanic faults

Moderate to strong hydrothermal alteration

Massive, semimassive, and impregnation sulfide ores

Medial facies association (= volcano flanks)

Margins of cryptodomes, sills, and lavas (facies 1)

In situ hyaloclastite breccia (facies 7)

Sediment-matrix hyaloclastite breccia (facies 8 )

Stratified (resedimented) hyaloclastite breccia (facies 17)

Medium thickness unit of thick-bedded, normal- to double-graded, pumiceous breccia-sandstone (facies 15 )

Medium thickness unit of heterogeneous pumice breccia and ashsandstone (facies 9)

Weak to moderate hydrothermal alteration

Distal facies association (= volcano margin)

None or one generation of sill or lava (facies 1)

Stratified (resedimented) hyaloclastite breccia (facies 17)

Thin unit of normal-graded pumiceous breccia-sandstone beds (facies 15)

Thin unit of heterogeneous pumice breccia and ash-sandstone (facies (9)

Intercalations of mudstone and sandstone turbidites (facies 25)

Weak to moderate pervasive diagenetic alteration

Facies numbers refer to Table 2

The area of most rhyolite intrusions, and the thickest interval of the tuff deposit $(50-300 \mathrm{~m})$, is interpreted as the proximal near-vent area (Table 4, Fig. 14). Lateral facies changes away from the proximal area mainly comprise a decrease in the number of intrusions and the thickness and grain size of the tuff unit, and an increase in ambient basinal facies and distal facies from adjacent volcanoes.

Most of the tuff deposits consist of one or more, 10 to 100 $\mathrm{m}$ thick (up to $300 \mathrm{~m}$ thick at Långdal), normal-graded or double-graded, pumiceous breccia and sandstone units (facies 15). We attribute these to subaqueous mass flows of pyroclastic debris that were fed from a pumiceous pyroclastic eruption column at the vent. Double-graded units are successions of beds in which each bed is normal graded and the whole succession becomes thinner bedded and finer grained upward (e.g., Petiknäs North 420-620 m, Fig. 8G). The rhyolitic pyroclastic unit at the Renström mine (Fig. 8E, 380$430 \mathrm{~m}$ ) is a more heterogeneous pumice breccia, with matrixsupported intervals of pumice blocks in an ash-siltstone matrix and without distinct grading or lithic clasts. We attribute this unit to a combination of direct subaqueous suspension fallout from a pyroclastic eruption column, and the delayed settling of pumice blocks that initially floated to the sea surface, then became waterlogged and sank.

The very thick, normal to double-graded, subaqueous mass flow bedforms imply that many of the tuff deposits were probably ponded within local topographic depres- sions and came to rest with a subhorizontal upper surface, or a low-angle cone-shaped surface sloping gently away from the vent area. Considering the regional structural setting (see below) and the various substrates on which the rhyolite volcanoes were built (Fig. 8), the local depressions probably included grabens, half-grabens, small calderas, and valleys between older rhyolitic to andesitic domes and cryptodomes.

Subsidence accompanied and followed the main pyroclastic eruption(s) at least in some cases (e.g., Renström, see below), but it is also likely that accumulation of the main pyroclastic unit resulted in net growth toward sea level in some cases. Furthermore, the subsequent intrusion of cryptodomes and sills into, and below, the tuff deposits disrupted and inflated the tuff deposits, and in many cases, presumably domed up the surface into a mound (Fig. 14). At Holmtjärn, local relics of rhyolitic volcaniclastic sandstones and conglomerates with traction current bedforms, scours, and rounded rhyolite clasts (facies 18, 21, Table 2) occur between the rhyolite intrusions. This indicates that the summit of the volcano emerged above the wave base and was partially eroded during the active life of the volcano. Subaerial to shallow-water facies were not observed at the other rhyolite cryptodome-tuff volcanoes; the exact locations of the volcano summits are not known and it is possible that several of the volcanoes grew to near sea level either during accumulation of the main pyroclastic unit or during inflation caused by subsequent intrusions. Many of the rhyolite porphyry cryptodome-tuff volcanoes may have been entirely subaqueous. We envisage that the morphology of the volcanoes included island volcanoes, seamounts, and irregular low mounds on the sea floor.

Basalt is intimately associated with several of the rhyolite cryptodome-tuff volcanoes. At Långdal, a swarm of green, fine-grained basalt sills with hyaloclastic margins intrudes the pumice-breccia tuff deposit and the lower part of the overlying succession (Fig. 8A). The tuff deposit is the footwall and host unit to the massive sulfide ores. The sills are altered and locally mineralized and therefore predate the end of mineralization. The hyaloclastic margins indicate emplacement while the pumice breccia succession was still wet and unlithified. At Viterberget (Renström domain), variably dismembered hyaloclastic basalt blocks occur in the subaqueous mass flow units of the tuff succession. These blocks indicate that a basalt lava or intrusion was in the vent area at the time of the pyroclastic eruption. Rhyolitic pumiceous subaqueous mass flow units in the lower part of the Petikträsk succession (Fig. 8I) are interpreted as proximal to medial deposits of a rhyolite cryptodome-tuff volcano. These units are monomict except for scattered, small, mafic hyaloclastite clasts. The basalt clasts have the same significance as those at Viterberget. They suggest that intrusion of basalt into the rhyolite cryptodome-tuff volcanoes was relatively common and may have triggered pyroclastic eruptions (cf. Sparks et al., 1977). Detailed petrogenesis of these rhyolitic volcanoes and their relationship to dacites, andesites, and basalts in the same domains await future study. At the moment we are uncertain as to whether the rhyolite cryptodome-tuff magmas are fractionated end members of the more mafic magmas or whether they form separate suites. 


\section{Subaqueous inyolite cryptodome-tuff volcano model}

A)

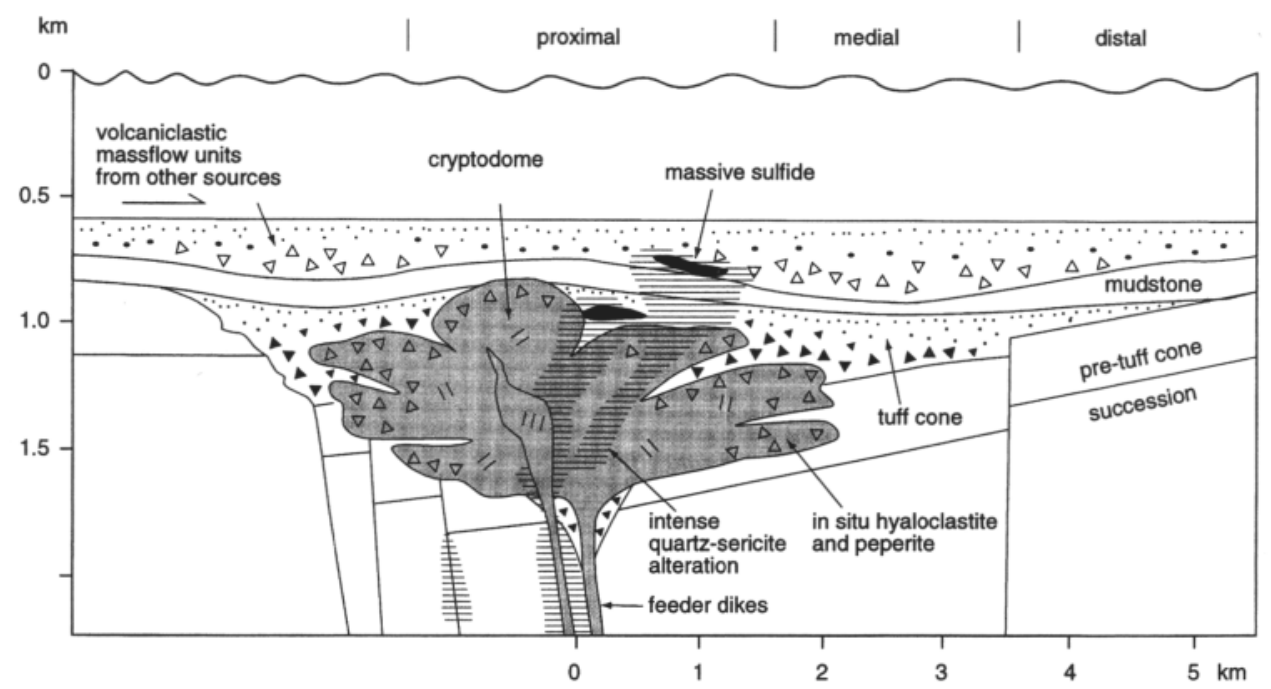

B)

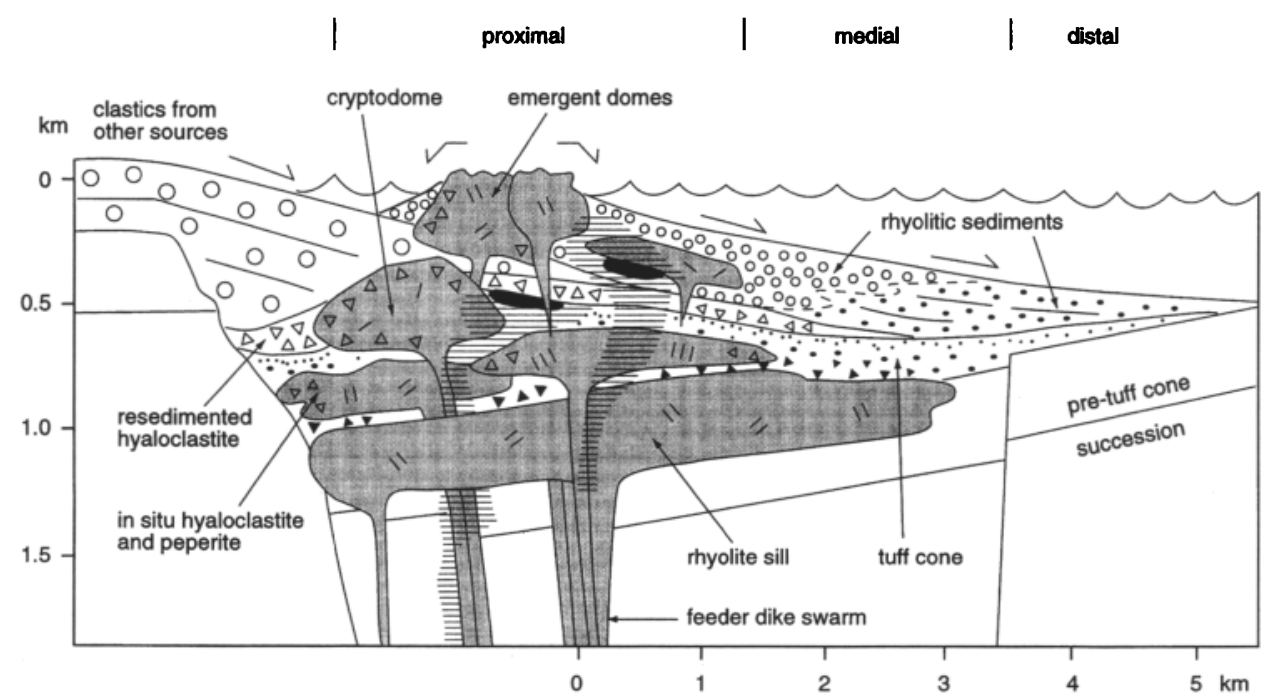

FIG. 14. Facies models for subaqueous rhyolite cryptodome-tuff volcanoes and massive sulfide ores: (A) with a small number of post-tuff intrusions, and (B) many post-tuff intrusions.

Tectonic, Volcanic, and Paleogeographic Evolution Skellefte Group: A continental margin volcanic arc under extension

The composition and facies architecture of the complete Skellefte district volcanic and sedimentary succession is unknown because the base of the succession is not exposed. However, the facies architecture and mainly marine paleoenvironments of the upper $7 \mathrm{~km}$ recognized in this study (Skellefte plus Vargfors Groups), the abundant calc-alkaline arc-type volcanic compositions determined from major, trace element, and rare earth element (REE) geochemistry, and the location of the district between a continental province with older Precambrian basement to the north, and a longlived marine basin to the south suggest that the Skellefte district is part of a volcanic arc (Hietanen, 1975; Lundberg, 1980; Rickard, 1986; Vivallo and Claesson, 1987). Based mainly on geochemistry, most authors have favored an oceanic island-arc model. However, well-studied volcanic arcs on oceanic crust, even those with periods of strong extension, are invariably dominated by andesite and basalt (cf. Ewart, 1982; Gamble et al., 1994; Fig. 10). Compared to young arc terranes, the composition of individual domains in the Skellefte Group and the overall felsic-dominant composition of the group (Fig. 10) are most similar to the compositions of arcs on continental or mature arc crust, especially arcs with strong extension and subsidence (cf. Konda, 1974; Cole, 1984; Gamble et al., 1994; Fig. 10). Regional facies architecture and stratigraphy also indicate that there is no major structural discordance between the Skellefte, Vargfors, and continental 
Arvidsjaur groups (Fig. 4). Consequently, the Skellefte arc developed directly adjacent to the continental Arvidsjaur Group region as originally proposed by Eklund (1923). The scenario that a primitive oceanic Skellefte arc developed independently and then collided with the continental region (e.g., Rickard, 1986) is not supported by the field evidence.

The facies analysis in this study shows that throughout development of the Skellefte Group, the district was a complex mixture of shallow-water and moderately deep-water areas, with the latter dominant. The over 3-km-thick Skellefte Group succession must have continually subsided and had a total subsidence of over $3 \mathrm{~km}$ to maintain this paleogeography. This submerged paleogeography is unusual for felsicdominant arc successions, but typical of felsic-dominant arcs with major massive sulfide districts (Sato, 1974; Allen, 1992; Corbett, 1992; McPhie and Allen, 1992). We argue that the facies characteristics and interpreted paleogeography alone suggest that the arc was under strong extension. Extension must have been sufficient to allow subsidence to keep pace, both with the rapid accumulation of strata during the intense phase of Skellefte Group volcanism and with the physical and thermal doming caused by shallow intrusion of voluminous synvolcanic magmas. The structural expression of extension and subsidence in the Skellefte Group comprises synvolcanic normal faults, which can be interpreted in well-mapped areas. For example, in the Petikträsk-Maurliden-Gallejaur area the abrupt changes in Skellefte Group stratigraphy yet minor changes in Vargfors Group stratigraphy across faults (rightcenter of Fig. 7) indicate active normal faulting prior to deposition of the Vargfors Group.

Claesson (1985), Vivallo and Claesson (1987), and Vivallo and Willdén (1988), concluded that large areas of the Skellefte district have a strongly bimodal composition and proposed an intra-arc rift setting for the district. Summarizing recent studies of young arcs, Smellie (1994) concluded that subhorizontal extension perpendicular to the arc is extremely common in convergent arc systems and that volcanism in most arcs is contemporaneous with normal faulting and subsidence. Our data support a strongly extensional arc setting and the association of volcanism with subsidence; however, the Skellefte Group as a whole is not bimodal (Fig. 10) and we have not observed any districtwide bimodal stratigraphic interval. Bimodal compositions are restricted to individual domains (e.g., Petikträsk(?), Fig. 10), and to narrow stratigraphic intervals within individual domains.

\section{Vargfors and Arvidsjaur Groups: Differential uplift, extension, and renewed continental-arc volcanism}

The top contact of the Skellefte Group corresponds to a decrease in the abundance of syneruptive volcanic facies. The contact also coincides with disconformities in parts of the Rakkejaur-Näsliden (Mensträsk), Maurliden, Petikträsk, and Boliden domains. These contacts and disconformities in the different domains are probably diachronous, because the volcanoes in different domains were unlikely to have stopped erupting at the same time, and the differences in the overlying stratigraphy of the Vargfors Group from one domain to the next indicate different structural and sedimentary histories. The base of the Vargfors Group, just above the basal disconformities and conformities, varies from deep-water mudstone and turbidite facies (e.g., Boliden and Hälträsk domains), to upward-shallowing prograding deltaic facies (e.g., Långtjärn and Vargfors, eastern Maurliden domain), to shallow-marine lime-matrix pebbly sandstone facies (northern margin of Maurliden domain), and fluvial-deltaic conglomerate facies (e.g., Petikträsk; Fig. 8).

We conclude that the change from Skellefte Group to Vargfors Group marks both the end of a major phase of intense arc volcanism and uplift in many parts of the district, resulting in disconformities. Uplift was most likely in response to the relaxation of crustal extension and the emplacement of some large intrusions to shallow crustal levels. Field relationships suggest that at least a part, and possibly a major part, of this uplift was related to intrusion of some early members of the Jörn granitoid suite. Radiometric dates of early members of the Jörn suite are imprecise (Wilson et al,, 1987); however, these granitoids intruded to shallow depths $(2-4$ ? $\mathrm{km}$, indicated by porphyritic margins and resorption textures, M. Einaudi, pers. commun., 1993), and within $3 \mathrm{~km}$ of the top of the Skellefte Group. Consequently, some of these granitoids were probably emplaced at the end of Skellefte Group volcanism (which has an age of $1882 \pm 8 \mathrm{Ma}$ in the Petikträsk area; Welin, 1987). Boulders from two or more granitoids become abundant in the Vargfors Group well below the stratigraphic level of the ignimbrite in the middle of the group (Fig. 8L). This ignimbrite has an age of $1877 \pm 3$ Ma (Billström and Weihed, 1996). Consequently, sufficient uplift $(3-4$ ? $\mathrm{km})$ to cause the unroofing and erosion of two or more granitoids occurred between deposition of the upper part of the Skellefte Group and the lower to middle part of the Vargfors Group, an interval of perhaps 5 m.y. or less (see above).

The end of Skellefte Group volcanism and the early uplift were followed and/or accompanied by differential uplift and subsidence of the Skellefte arc into a complex horst and graben paleogeography with different facies patterns of Vargfors sedimentation in different fault blocks (Fig. 4B). Secondorder horsts and grabens were superimposed on a regional first-order pattern. Basal coarse clastic rocks of the Vargfors Group (Mensträsk conglomerate) were locally derived fluvialdeltaic erosional products of fault scarps and uplifted blocks. These facies were restricted to particular fault blocks in the second-order horst and graben pattern. The facies pattern changes upward to both fine-grained and coarse-grained sediments that extend across relatively large areas (Elvaberg Formation, Abborrtjärn conglomerate, Fig. 4B). This change is attributed to the filling of the second-order horst and graben topography, after which fluvial-deltaic sediments prograded across more regional (first-order?) grabens.

Subsequently, large volumes of moderate to high $\mathrm{Mg}$ pyroxene-porphyritic basalts were erupted (Gallejaur volcanics), minor andesite-dacite-rhyolite volcanism occurred (Gallejaur volcanics), and detritus from major terrestrial felsic volcanism to the north (Arvidsjaur Group) was shed into the basin. These events are suggestive of crustal extension, incipient rifting resulting in the tapping of primitive mafic magma, continued subsidence in the area of the Skellefte arc, and renewed but more continental arc volcanism to the north. 


\section{Setting of Massive Sulfide Ores}

Relationship to tectonic evolution and regional stratigraphy

In order of decreasing abundance, massive sulfide ores occur at the top of the Skellefte Group, within the Skellefte Group, and in the basal sediments of the overlying Vargfors Group (Fig. 4A and B). This regional stratigraphic interval corresponds to the period of intense extensional arc volcanism, especially the end of this period. We suggest that the ores in the base of the Vargfors Group are essentially related to Skellefte Group volcanism, because we found evidence that Skellefte Group volcanism continued during deposition of the basal part of the Vargfors Group. For example, at the northern margin of the Maurliden domain, a rhyolite porphyry sill identical to some rhyolites in the Maurliden domain intrudes into the base of the Vargfors Group sediments (Fig. 7). In the Boliden-Långsele-Långdal area, the base of the Vargfors Group sedimentary succession has a 100 - to $300-\mathrm{m}$ thick interval with interbeds of syneruptive, subaqueous mass flow units of pyroclastic debris (Figs. 5 and $8 \mathrm{~A}-\mathrm{C}$ ). These syneruptive mass flow units are interpreted as medial facies from the last eruptions of Skellefte Group volcanoes in adjacent areas. This relationship highlights the diachronous and interfingering character of the boundary between the Skellefte and Vargfors Groups.

At the subregional scale, the massive sulfide ores occur mainly at the top of individual volcanoes or volcanic complexes of the Skellefte Group and near the contact with overlying sedimentary facies or medial to distal volcanic facies of adjacent volcanic centers.

\section{Relationship to depositional environment}

Important studies in the Hokuroku district of Japan (Ohmoto and Skinner, 1983) have influenced many workers to conclude that volcanic-associated massive sulfide ores are restricted to very deep-water environments of 1,000 to 4,000 m (e.g., Rickard, 1986). However, our results suggest that this interpretation is not applicable to the Skellefte district. During the period of massive sulfide mineralization, the Skellefte district had a marine paleogeography with many scattered shallow-water areas and islands. The exact water depth of the deeper environments between these shallow areas cannot be determined from volcanological and sedimentological studies, but they were below storm wave base, which generally lies within the range of a $50-$ to $100-\mathrm{m}$ water depth (Johnson and Baldwin, 1986). All the major massive sulfide deposits, except possibly the Mensträsk ores, occur in these below-storm wave base facies associations (Fig. 13). However, several of the massive sulfide deposits are close to stratigraphic intervals of shallow water-subaerial facies associations. Examples include Holmtjärn, Renström, Petiknäs South, West Maurliden, and Boliden, which are described below.

The Holmtjärn massive sulfide deposit occurs in a facies association of alternating polymict conglomerate, sandstone, gray mudstone, and rhyolite sills (Fig. $8 \mathrm{H}$ ). The abundant rounded cobbles indicate a subaerial-shallow marine source area for the clastic debris. The local preservation of gray mudstone suggests that the depositional environment may have been below the wave base. However, most of the con- glomerate and sandstone beds do not have the distinct subaqueous mass flow bedforms with normal-graded tops that are characteristic of the deep-water mass flow successions. Instead, most beds are moderately to well sorted and have massive bedforms or are stratified due to vertical fluctuations in grain size. From $15 \mathrm{~m}$ above the massive sulfide ore, the facies association changes to diffusely stratified polymict conglomerate, subordinate sandstone, and no mudstone interbeds. These facies associations indicate deposition mainly from channelized, proximal mass flows and traction currents. We interpret this setting of the Holmtjärn ore deposit as the proximal to medial part of a coarse sediment fan (fan delta) entering into the marine environment and interfingering with the Holmtjärn rhyolite cryptodome-tuff volcano (Fig. 14B). Fan-deltas generally occur on downthrown fault blocks adjacent to fault scarps, and we suggest that the fan-delta at Holmtjärn was sourced from a fault scarp in the Holmtjärn region. Progradation of the fan-delta into the marine environment would have resulted in upward-shallowing successions. The stratigraphic level of the ore deposit probably represents below-wave base conditions, but probably less than $500 \mathrm{~m}$ deep.

In the Renström area, the Renström and Kyrkväg massive sulfide deposits are separated by a thick dacite-andesite sill and fault (Fig. 6). Correlation of the stratigraphies west and east of the sill and fault (Fig. 8E) suggests that the massive sulfides are repetitions of the same original ore deposit. An extensive unit of reworked andesitic volcaniclastic rocks occurs just $45 \mathrm{~m}$ stratigraphically below the Kyrkväg deposit and is inferred to underlie the Renström deposit (Figs. 8E, 12 , and 13; facies 21 , Table 2). Red oxidation, together with abundant scours, erosion surfaces, cross bedded coarsegrained sandstones, lensoidal stratification, and channels (Fig. 12), provides diagnostic evidence of shallow-water to subaerial conditions. This unit is part of a transgressive sequence that grades stratigraphically upward into normal-graded andesitic volcaniclastic beds deposited below the wave base, and then andesitic followed by rhyolitic, water-settled pumice deposits (facies 9, Table 2; Fig. 8E). The Renström and Kyrkväg ores occur in the latter and are stratigraphically overlain by black mudstone and rhyolitic sandstone turbidite facies (facies 25), which suggest water depths well below the storm wave base (i.e., $100 \mathrm{~m}$ or more). We do not recognize the evidence for shallow-water conditions at the Renström mine reported by Duckworth (1991), such as welding textures, accretionary lapilli, flaser bedding, and stromatolite textures, but the conclusion from fluid inclusion studies (Broman, 1987) that the ores might have formed at water depths as shallow as $200 \mathrm{~m}$ is consistent with our data.

In the Petiknäs South structural block (Fig. 6), a thick succession of andesitic breccias and sandstones with abundant traction current stratification (Fig. 12; facies 18, Table 2), occurs 200 to $300 \mathrm{~m}$ stratigraphically below the massive sulfide ores (Fig. 8F). We interpret this andesitic succession as shallow-water to subaerial deposits (Fig. 13); however, the immediate footwall to the massive sulfide ores and the hanging-wall succession comprise below-wave base facies associations (Fig. 8F).

The West Maurliden massive sulfide is overlain by a normal-graded subaqueous mass flow unit, gray tuffaceous silt- 
stone, and a hyaloclastitic lava or intrusion (Fig. 8K). This facies association indicates a subaqueous, probably belowwave base depositional environment, but stratified conglomerate and sandstone (facies 21) along strike to the west, and lime-matrix breccia-conglomerate (facies 11) $250 \mathrm{~m}$ into the stratigraphic hanging wall to the south, are interpreted as subaerial-shallow marine and shallow-marine deposits, respectively. The abundance of areas and stratigraphic intervals of a shallow-water to subaerial depositional environment in this central part of the district (Fig. 13) could partly explain the restricted occurrence and generally low base metal grades of massive sulfides in the central part of the district, assuming that below-wave base environments were most conducive for the genesis and preservation of the massive sulfide ores. The abundance of hydrothermal brecciation in this part of the district could also result from the low hydrostatic confining pressure enforced on the hydrothermal systems by the shallow-water environments.

The complex Boliden deposit occurs in a succession of andesitic sills, lavas and volcaniclastic rocks, dacitic intrusions, a rhyolitic intrusion(?) and rhyolitic subaqueous volcaniclastic mass flow units (Fig. 8C; see also Bergman Weihed et al., 1996). No evidence of the depositional environment is found directly adjacent to the massive sulfide ore, but abundant hyaloclastites occur in a similar stratigraphic position to the north, and relics of subaqueous mass flow units occur slightly lower in the stratigraphy to the west. These data suggest that the host rocks to the ore were emplaced in a subaqueous environment. The timing relationships between the various ore types, alteration zones, and host facies are uncertain; however, a part of the alteration envelope (see above) overprints, and therefore postdates, a large dacite intrusion in the apparent stratigraphic hanging wall to the south (Fig. 5). This dacite was studied in many drill cores and has implications for the depositional environment of the Boliden area. The dacite has a complexly interfingering, fine-grained chilled intrusive base but a simpler sharp concordant top surface with no chilled zone. Dacite debris identical to the dacite intrusion occurs locally at this surface and as a debris flow unit in the overlying succession. The top surface of the dacite intrusion is interpreted here as an approximately planar, shallow-marine erosion surface. The intrusion is overlain by a blanket of rhyolitic pyroclastic debris, which also has a sharp, nongraded, eroded top (Fig. 8C). This blanket of rhyolitic debris is in turn onlapped by a well-stratified Vargfors Group succession of subaqueous mass flow units and gray-black mudstone (Fig. 8C). These relationships indicate that prior to the end of alteration at the Boliden ore deposit, the area was exposed (uplifted?) above the wave base, eroded, and subsequently submerged below the wave base again. Consequently, if the Boliden ore deposit is synvolcanic, then the hydrothermal system would have experienced this major fluctuation in depositional environment. This could partly explain why the Boliden deposit has characteristics of both submarine massive sulfide mineralization and epithermal mineralization (high alumina alteration, high $\mathrm{Au}-\mathrm{As}-\mathrm{Sb}-\mathrm{Te}-\mathrm{Se}$ contents, Table 1).

\section{Relationship to rhyolite cryptodome-tuff volcanoes}

Although subaqueous rhyolite cryptodome-tuff volcanoes are a small component (5\% or less) of the Skellefte district, many massive sulfide ores are intimately associated with them. Most of the ores occur at the top of these volcanoes or in the base of the overlying successions. All of the ores occur within or directly above the proximal facies association of the volcanoes (Fig. 14).

In addition, several other massive sulfide deposits that superficially appear related to other volcano types, actually coincide with an intercalation of proximal to medial facies from a rhyolite cryptodome-tuff volcano. Hälträsk and West Maurliden are instructive examples. The small Hälträsk massive sulfide deposit occurs near the top of an extremely thick andesitic succession, interpreted as the medial facies association of a major marine andesite volcano. Rhyolites are extremely rare in this succession (Figs. $8 \mathrm{M}$ and 10), but an interval of strongly chlorite-altered, rhyolitic subaqueous pumice breccia-sandstone mass flow units with large round quartz phenocrysts occurs stratigraphically just below the sulfide deposit.

The West Maurliden massive sulfide deposit occurs within a thick succession of fine-grained feldspar-porphyritic rhyolite, dacite and andesite lavas, intrusions, and associated volcaniclastic facies, which is defined in this study as the Maurliden emergent marine rhyolite-dacite-andesite lava-cryptodometuff complex (Table 3). Coarse rhyolite porphyries with large round quartz phenocrysts are scattered through this succession and are interpreted as subvolcanic intrusions (Fig. 7). It is remarkable that the West Maurliden massive sulfide coincides exactly with a 70-m-thick interval of rhyolitic volcaniclastic debris with large round quartz phenocrysts, the only such unit known in the succession (Fig. 8K). The quartzphyric rhyolite debris is interpreted as a medial(?) facies sourced from eruption of one of the coarse intrusive porphyry cryptodomes. The coincidence of the ore with this facies, and the near-sea-floor emplacement origin of the ore (see below), indicate that the ore formed immediately after the eruption of a very coarse-grained rhyolite cryptodome.

These relationships indicate a remarkable coincidence in space and time between massive sulfide ores and the rhyolite cryptodome-tuff volcanoes. The existing, favored, ore genetic model of a regional convective hydrothermal system with ore precipitation at the sea floor above fault conduits (Rickard, 1986) is insufficient to explain the remarkable coincidence of ores with one particular volcano type. Synvolcanic faults were common in the Skellefte district and presumably provided the conduits both for ascending hydrothermal solutions and for the magmas of all the various volcano types in the district. The remarkable coincidence of massive sulfide ores with the rhyolite cryptodome-tuff volcanoes requires that many of the ores were intimately and genetically linked to the tectonic and magmatic evolution of this specific volcano type (in addition to links with regional tectonic and magmatic evolution, and depositional environment).

\section{Relationship to other volcano types}

A few massive sulfide ores in the areas studied have a spatial relationship to dacite-andesite-basalt complexes and no known distinct association with the rhyolite volcanoes (e.g., Kankberg, Bastuheden). The timing and origin of these ores are unclear and require further work. 


\section{Relationship of ore type to volcanic facies association}

Relationships between metal ratios (and economic viability) of the ores and volcanic facies association are mainly indistinct. Ores associated with rhyolite cryptodome-tuff volcanoes tend to be relatively enriched in $\mathrm{Zn} \pm \mathrm{Pb}$, and to a lesser extent $\mathrm{Au}$ (Fig. 3) but include both high-grade economic ores and low-grade ores with high As and Sb contents. There may also be a tendency for the less economic and smaller massive sulfide ores to occur in medial rather than proximal facies associations (e.g., Hälträsk, W. Maurliden?) and in regions with abundant subaerial-shallow-water environments (Mensträsk, W. Maurliden). However, the small but very high-grade Holmtjärn deposit also occurs in a relatively shallow-water environment.

\section{Ore host facies: Evidence for abundant subsea-floor replacement ores}

The emplacement mechanism of host facies to mineralization provides critical data on the origin of the mineralization (Allen, 1994). Massive sulfides deposited on the sea floor must occur in facies of low sedimentation rate, such as pelagic and hemipelagic mudstones. With the exception of clastic transported ores, mineralization within rapidly or mass emplaced facies such as mass flow units and intrusions, must postdate its host rock and have formed by subsurface replacement or infiltration.

Many massive sulfide ores in the Skellefte district occur within rapidly or mass emplaced volcaniclastic facies and must therefore be regarded as replacement and impregnation ore deposits. Examples include Renström which occurs within a subaqueous pumiceous pyroclastic fallout unit (Fig. 8E), Petiknäs North which occurs in the lithic-rich base of a mass flow breccia (Fig. 8G), Holmtjärn which occurs within a polymict mass flow volcanic conglomerate (Fig. $8 \mathrm{H}$ ), West Maurliden which replaces a quartz-phyric rhyolitic volcaniclastic unit (Fig. $8 \mathrm{~K}$ ), and Långdal and the lower lenses of the Långsele deposit which both occur within massive, syneruptive pumice breccia mass flow units (Fig. 8A and B). These massive sulfide deposits range from truely massive, to semimassive and impregnation ores (refer to sulfur contents, Table 1). All of the ores contain at least local relics of the host facies within them. Some other massive sulfide ores in the Skellefte district may have been emplaced on the sea floor.

The distance below the sea floor at which infiltration and replacement occurred is more difficult to interpret. At West Maurliden, the top of the massive sulfide coincides exactly with the top of the rhyolitic volcaniclastic host unit, and alteration decreases rapidly in intensity above the ore (Fig. $8 \mathrm{~K}$ ). It is possible therefore that the top of the rhyolitic volcaniclastic host unit was the sea floor at the time of ore formation, and replacement occurred right up to the sea floor. The Långsele ore deposit (Fig. 8B) has an irregular geometry. Ore at the top of the rhyolitic pyroclastic unit and directly below the overlying black mudstone may have formed in a fashion similar to that described for West Maurliden. However, the lower lenses and tongues of ore occur within the rhyolite pyroclastic unit and are interpreted to have replaced that unit. Consequently, at Långsele, infiltration and replacement may have occurred at a range of stratigraphic levels over an interval of $150 \mathrm{~m}$. At Holmtjärn, strong pyritic alteration extends more than $150 \mathrm{~m}$ into the hanging wall without any abrupt breaks in intensity. Consequently, the stratigraphic depth at which replacement occurred is unresolved.

All of the replacement-type massive sulfide ores have replaced originally very porous and permeable host facies, especially pumiceous facies. These very porous facies would have originally been saturated with cold seawater. Prior to compaction, the pumiceous facies may have contained 70 to 90 percent by volume of sea water. It seems logical therefore that the main reason for abundant replacement ores in the Skellefte district is the abundance of originally very porous volcaniclastic facies, which caused the upwelling hydrothermal solutions to mix with cold seawater and precipitate their metals prior to reaching the sea floor. By contrast, hydrothermal solutions flowing up fault conduits or local breccia zones in massive lava piles would not meet such large volumes of cold sea water until reaching the sea floor.

The discontinuous, semimassive to spotty carbonate-rich alteration halos that were described above, also mainly occur within pumiceous facies and are associated with replacement ores. These data suggest a general genetic model in which an interface developed between ascending hydrothermal solutions and the overlying or surrounding cold seawater-saturated strata. Sulfides were precipitated along the lower side of this interface, whereas carbonates (and anhydrite?) formed along and outside the interface. The carbonates may have precipitated from seawater and be analogous to the gypsum zones of the Japanese kuroko deposits. The sedimentary or sea water signature of $\mathrm{C}$ and $\mathrm{O}$ isotope data from carbonates at Renström (Duckworth, 1991) are consistent with this interpretation. Deposition of carbonate and other gangue minerals at a subseafloor interface may also have provided permeability and chemical barriers that further focused sulfide precipitation.

\section{A range in ore deposit type, from volcanic-hosted massive} sulfide toward epithermal

Many sulfide deposits in the Skellefte district have characteristics of marine synvolcanic massive sulfide deposits (see above). Several deposits also have some characteristics more common to subvolcanic and epithermal deposits. These include moderately shallow-water depositional environments of the host succession, high $\mathrm{Au}, \mathrm{As}, \mathrm{Sb}$, and $\mathrm{Hg}$ contents, replacement- and infiltration-style mineralization, extensive hydrothermal brecciation, and local high alumina alteration. We suggest that massive sulfide ores in the Skellefte district span a range in ore deposit style from deep-water sea-floor ores, to subsea-floor replacements, to shallow-water and possibly subaerial synvolcanic replacements.

\section{Conclusions: Stratigraphic and Volcanological Guides to Prospecting for Massive Sulfide Ores Based on the Skellefte District}

1. Massive sulfide ores occur within and at the top of the stratigraphic interval that corresponds to the period of intense extensional arc volcanism.

2. Within this regional stratigraphic interval the ores occur near the top of eruptive cycles, which represent the evolution of individual volcanoes or complexes of volcanoes.

3. Bimodal rhyolite-basalt stratigraphic intervals are espe- 
cially prospective but are not essential to the location of good massive sulfide deposits.

4. Most ores are intimately associated with rhyolitic cryptodome-tuff volcanoes characterized by a subaqueous pyroclastic unit intruded by multiple generations of cryptodomes, sills, and dikes.

5. The ores occur mainly within the proximal facies association of these rhyolite volcanoes. The characteristic proximal, medial, and distal facies associations of these volcanoes can be used as facies vectors to locate the prospective proximal vent area.

6. Some ores are associated with relatively thin intervals of the rhyolitic cryptodome-tuff volcanoes encased within a stratigraphic succession of different character.

7. Hanging-wall facies associations to the massive sulfide ores include basaltic lavas and sills, mudstone-turbidite-volcaniclastic mass flow successions, and the medial to distal subaqueous mass flow facies of adjacent volcanoes.

8. The ores are almost entirely restricted to below-wave base facies associations and do not occur in areas dominated by above-wave base facies associations. However, the summits of some volcanoes that host massive sulfides emerged above sea level, and the ores can occur close to areas or stratigraphic intervals of above-wave base facies associations.

9. Massive sulfide ores do not necessarily occupy a seafloor horizon. The ores occur over a stratigraphic interval reaching up to $150 \mathrm{~m}$ or more below the sea-floor position corresponding to the time of mineralization. Drilling patterns can be designed to test routinely for these subsea-floor ore lenses.

These guides to ore should, of course, be integrated with other geologic, geochemical, and geophysical techniques in any exploration program.

\section{Synthesis: The main locus of massive sulfide mineralization}

The single most prospective position for massive sulfide ores in the Skellefte district is a combination of the top of proximal facies associations in a rhyolite cryptodome-tuff volcano, a below-wave base depositional environment, and a stratigraphic level near the top of the Skellefte Group. However, several important deposits, including the Kristineberg deposit and all of the Renström domain deposits, do not occur near the top of the Skellefte Group. Therefore the relationship to individual rhyolite volcanoes may be more critical than the regional stratigraphic level. For example, in the Renström domain (Figs. 8, 13), three major massive sulfide deposits are known. Each major deposit occurs at the top of the proximal facies association of a separate rhyolite volcano. Although correlations between the different structural blocks in the Renström domain are uncertain, the stratigraphies enclosing each of the major massive sulfide deposits are different and cannot be correlated. Consequently we conclude that each mineralized rhyolite volcano in the Renström domain, and therefore each massive sulfide deposit, is at a slightly different stratigraphic level.

\section{Acknowledgments}

We thank Lars Persson, Leif Björk, and Ingmar Lundström (Geological Survey of Sweden) for initial encouragement to start this project, and the National Board for Industrial and Technical Development, the Swedish Mining Industry Research Organization, their national ore geology research program, and the Geological Survey of Sweden for support of the project. Boliden $A B$ contributed enormously via logistical support, encouragement, and the knowledge of their staff. We especially thank Wiking Andersson, Ivan Isaksson, Rolf Jonsson, Benny Mattsson, Christian Trepka-Bloch, Roger Nordin, Mats Willdén, Juhani Nylander, Rolf Larsson, Robert Pantze, Bertil Sandström, Annika Wasström, and Henrik Sundén from Boliden $\mathrm{AB}$. We also thank Lennart Widenfalk (Luleå University), Bengt Sjöblom (Cogema), Jeanette Bergman Weihed (Uppsala University), Kjell Billström (Museum of Natural History), and Ulf Bergström, Anders Hallberg, and Anna Åberg (Geological Survey of Sweden) for helpful discussions and for guiding us to some of their favorite outcrops. Economic Geology reviewers are thanked for several suggestions, which substantially improved the manuscript.

\section{REFERENCES}

Allen, R.L., 1988, False pyroclastic textures in altered silicic lavas, with implications for volcanic-associated mineralization: ECONOMIC GEOLOGY, v. 83 , p. $1424-1446$.

-1990, Subaqueous welding, or alteration, diagenetic compaction and tectonic dissolution? [abs.]: International Association of Volcanology and Chemistry of the Earth's Interior International Volcanological Congress, Mainz, Germany, September 1990, Abstracts volume, p. 2.

1992, Reconstruction of the tectonic, volcanic and sedimentary setting of strongly deformed $\mathrm{Zn}$-Cu massive sulfide deposits at Benambra, Victoria: ECONOMIC GEOLOGY, v. 87, p. 825-854.

-1993, Rotten rocks, great mineral potential: Textural evolution of submarine volcanic rocks during diagenetic and hydrothermal alteration [abs.]: International Association of Volcanology and Chemistry of the Earth's Interior International Volcanological Congress, Canberra, Australia, September 1993, Abstracts volume, p. 2.

1994, Synvolcanic, subsea-floor replacement model for Rosebery and other massive sulphide ores [abs.]: Geological Society of Australia, Tasmania Division, Contentious Issues in Tasmanian Geology Symposium, Hobart, Australia, Abstracts, v. 39, p. 107-8.

Bergman Weihed, J., Bergström, U., Billström, K., and Weihed, P., 1996, Geology, tectonic setting, and origin of the Paleoproterozoic Boliden AuCu-As deposit, Skellefte district, northern Sweden: ECONOMIC GEOLOGY, v. 91, p. 1073-1097.

Billström, K., and Weihed, P., 1996, Age and provenance of host rocks and ores in the Paleoproterozoic Skellefte district, northern Sweden: ECONOMIC GEOLOGY, v. 91, p. 1054-1072.

Branney, M.J., and Sparks, R.S.J, 1990, Fiamme formed by diagenesis and burial compaction in soils and subaqueous sediments: Geological Society of London Journal, v. 147, p. 919-922.

Broman, C., 1987, Fluid inclusions of the massive sulfide deposits in the Skellefte district, Sweden: Chemical Geology, v. 61, p. 161-168.

Cas, R.A.F., and Wright, J.V., 1987, Volcanic successions: Modern and ancient. A geological approach to processes, products and successions: London, Allen and Unwin, $518 \mathrm{p}$.

1991, Subaqueous pyroclastic flows and ignimbrites: An assessment: Bulletin of Volcanology, v. 53, p. 357-380.

Cas, R.A.F., Allen, R.L., Bull, S.W., Clifford, B.A., and Wright, J.V., 1990, Subaqueous rhyolitic dome-top tuff cones-a model based on the Devonian Bunga Beds, southeastern Australia and a modern analogue: Bulletin of Volcanology, v. 52, p. 159-174.

Claesson, L-A., 1985, The geochemistry of Early Proterozoic metavolcanic rocks hosting massive sulfide deposits in the Skellefte district, northern Sweden: Geological Society of London Journal, v. 142, p. 899-909.

Cole, J.W., 1970, Structure and eruptive history of the Tarawera volcanic complex: New Zealand Journal of Geology and Geophysics, v. 13, p. 879902.

- 1979, Structure, petrology and genesis of Cenozoic volcanism, Taupo volcanic zone, New Zealand-a review: New Zealand Journal of Geology and Geophysics, v. 22, p. 631-657. 
-1984, Taupo-Rotorua depression: An ensialic marginal basin of North Island, New Zealand: Geological Society of London Special Publication 16 , p. $109-120$.

Corbett, K.D., 1992, Stratigraphic-volcanic setting of massive sulfide deposits in the Cambrian Mount Read volcanics, Tasmania: Economic Geology, v. 87 , p. $564-586$.

Duckworth, R.C., 1991, The geology and depositional environment of the Early Proterozoic massive sulfide-bearing sequence, Renström, northern Sweden: Unpublished Ph.D. thesis, University of Wales, College of Cardiff, $209 \mathrm{p}$.

Du Rietz, T., 1953, Geology and ores of the Kristineberg deposit, Västerbotten, Sweden: Sweden Geological Survey, series C, v. 524, 90 p.

Eklund, J., 1923, Skelleftefältets geologi: Geologiska Föreningens i Stockholm Förhandlingar, v. 45, p. 219-213 (in Swedish).

Ewart, A., 1982, The mineralogy and petrology of Tertiary-Recent orogenic volcanic rocks: With special reference to the andesitic-basaltic compositional range, in Thorpe, R.S., ed., Andesites: Orogenic andesites and related rocks: Chichester, Wiley, p. 26-87.

Gamble, J.A., Wright, I.C., Woodhead, J.D., and McCulloch, M.T., 1994, Arc and back-arc geochemistry in the southern Kermadec arc-Ngatoro basin and offshore Taupo volcanic zone, SW Pacific: Geological Society of London Special Publication 81, p. 193-212.

Gavelin, S., 1955a, Beskrivning till berggrundskarta över Västerbottens län: Sweden Geological Survey, series Ca, no. 37, 99 p. (in Swedish with English abstract).

1955b, Sulfide mineralization in the Skellefte district, northern Sweden, and its relationship to regional granitization: ECONOMIC GEOLOCY, v. 50, p. $814-831$.

Grip, E., 1951, Geology of the sulfide deposits at Mensträsk and a comparison with other deposits in the Skellefte district: Sweden Geological Survey, series C, v. $515,52 \mathrm{p}$.

Grip, E., and Wirstam, $\AA$., 1970, The Boliden sulfide deposit: A review of geo-investigations carried out during the lifetime of the Boliden mine, Sweden (1924-1967): Sweden Geological Survey, series C, v. 651, 68 p.

Helfrich, H.K., 1971, Stratigraphische, tektonische, petrochemische und montangeologische Zuge am Nordrand der zentralen "Norrlandsgeosynklinale": Sweden Geological Survey, series C, no. 654, 195 p. (in German with English summary).

Hietanen, A., 1975, Generation of potassium-poor magmas in the northern Sierra Nevada and the Svecofennian of Finland: U.S. Geological Survey Journal of Research, v. 3, p. 631-645.

Horikoshi, E., 1969, Volcanic activity related to the formation of the kurokotype deposits in the Kosaka district, Japan: Mineralium Deposita, v. 4, $321-345$.

Högbom, A., 1928, On the relation between syntectonic granites and ore formation in Sweden: Fennia, v. 50, no. 21, p. 1-14.

Johnson, H.D., and Baldwin, C.T., 1986, Shallow siliclastic seas, in Reading, H.G., ed., Sedimentary environments and facies: Oxford, Blackwell, p. $229-282$.

Kautsky, G., 1957, Ein beitrag zur stratigraphie und dem bau des Skelleftefeldes, Nordschweden: Sweden Geological Survey, series C, v. 543, 65 p. (in German with English summary).

Kokelaar, B.P., Bevins, R.E., and Roach, R.A., 1985, Submarine silicic volcanism and associated sedimentary and tectonic processes, Ramsey Island, SW Wales: Geological Society of London Journal, v. 142, p. 591-613.

Konda, T., 1974, Bimodal volcanism in the northeast Japan arc: Geological Society of Japan Journal, v. 80, p. 81-89.

Lilljequist, R., and Svenson, S- $\AA$., 1974, Exceptionally well preserved Precambrian ignimbrites and basic lavas in N. Sweden: Geologiska Föreningens i Stockholm Förhandlingar, v. 96, p. 221-229.

Lundberg, B., 1980, Aspects of the geology of the Skellefte field, northern Sweden: Geologiska Föreningens i Stockholm Förhandlingar, v. 102, p. $156-166$.

McPhie, J., and Allen, R.L., 1992, Facies architecture of mineralized submarine volcanic sequences: Cambrian Mount Read volcanics, western Tasmania: ECONOMIC GEOLOGY, v. 87 , p. 587-596.

McPhie, J., Doyle, M., and Allen, R.L., 1993, Volcanic textures: A guide to the interpretation of textures in volcanic rocks: Hobart, University of Tasmania, Centre for Ore Deposit and Exploration Studies, $198 \mathrm{p}$.

Nicholson, D., 1993, The paleoenvironmental setting and Au genesis of the Early Proterozoic Holmtjärn volcanogenic massive sulfide deposit, Skellefte district, northern Sweden: Unpublished Ph.D. thesis, University of Wales, College of Cardiff.

Nilsson, C.A., 1968, Wall rock alteration at the Boliden deposit, Sweden: ECONOMIC GEOLOGY, v. 63, p. 472-494.

Ödman, O.H., 1941, Geology and ores of the Boliden deposit, Sweden: Sweden Geological Survey, series C, v. 438, 190 p.

Ohmoto, H., and Skinner, B.J., 1983, The kuroko and related volcanogenic massive sulfide deposits: Introduction and summary of new findings: ECONOMIC GEOLOGY MONOGRAPH 5, p. 1-8.

Rickard, D., ed., 1986, The Skellefte field: Sweden Geological Survey, series $\mathrm{Ca}$, no. $62,54 \mathrm{p}$

Rickard, D.T., and Zweifel, H., 1975, Genesis of Precambrian sulfide ores, Skellefte district, Sweden: Economic Geology, v. 70, p. 255-274.

Sato, T., 1974, Distribution and geological setting of the Kuroko deposits: Society of Mining Geologists of Japan Special Issue 6, p. 1-9.

Skiöld, T., 1988, Implications of new U-Pb zircon chronology to Early Proterozoic crustal accretion in northern Sweden: Precambrian Research, v. 38 , p. $147-164$.

Skiöld, T., Öhlander, B., Markkula, H., Widenfalk, L., and Claesson, L$\AA$ A., 1993, Chronology of Proterozoic orogenic processes at the Archean continental margin in northern Sweden: Precambrian Research, v. 64, p. $225-238$.

Smellie, J.L., 1994, Volcanism associated with extension at consuming plate margins: Geological Society of London Special Publication 81, p. 1 .

Sparks, R.S.J., Sigurdsson, H., and Wilson, L., 1977, Magma mixing: A mechanism for triggering acid explosive eruptions: Nature, v. 267, p. 315-318.

Svenson, S-A.., 1982, Näsliden, a volcanogenic massive sulfide deposit in the Skellefte district, northern Sweden: Sweden Geological Survey, series C, no. $790,81 \mathrm{p}$

Trepka-Bloch, C., 1985, Cyclic ore formation of some volcanogenic massive sulfide deposits in the Skellefte district, Sweden: Mineralium Deposita, v. 20, p. $23-29$

1989, Volcanogenic and tectonic features of the Rakkejaur sulfide deposit, Skellefte district, Sweden: Mineralium Deposita, v. 24, p. 279-288.

Vivallo, W., and Claesson, L- $\AA$., 1987, Intra-arc rifting and massive sulfide mineralization in an Early Proterozoic volcanic arc, Skellefte district, northern Sweden: Geological Society of London Special Publication 33, p. $69-79$.

Vivallo, W., and Willdén, M., 1988, Geology and geochemistry of an early Proterozoic volcanic arc sequence at Kristineberg, Skellefte district, Sweden: Geologiska Föreningens i Stockholm Förhandlingar, v. 110, p. 1-12.

Weihed, P., 1992, Lithogeochemistry, metal and alteration zoning in the Proterozoic Tallberg porphyry-type deposit, northern Sweden: Journal jof Geochemical Exploration, v. 42, p. 301-325.

Weihed, P., Isaksson, I., and Svenson, S.-Å., 1987, The Tallberg porphyry copper deposit in northern Sweden: A preliminary report: Geologiska Föreningens i Stockholm Förhandlingar, v. 109, p. 47-53.

Weihed, P., Bergman, J., and Bergström, U., 1992, Metallogeny and tectonic evolution of the Early Proterozoic Skellefte district, northern Sweden: Precambrian Research, v. 58, p. 143-167.

Welin, E., 1987, The depositional evolution of the Svecofennian supracrustal sequence in Finland and Sweden: Precambrian Research, v. 35, p. 95113.

Wilson, C.J.N., Rogan, A.M., Smith, I.E.M., Northey, D.J., Nairn, I.A., and Houghton, B.F., 1984, Caldera volcanoes of the Taupo volcanic zone, New Zealand: Journal of Geophysical Research, v. 89, p. 8463-8484.

Wilson, M.R., Sehlstedt, S., Claesson, L.-Å., Smellie, J.A. T., Aftalion, M., Hamilton, P.J., and Fallick, A.E., 1987, Jörn: An Early Proterozoic intrusive complex in a volcanic arc environment, north Sweden: Precambrian Research, v. 36, p. 201-225.

Zweifel, H., 1982, Ore deposits in the Skellefte field-volcanic activity and depositional environment: Geologiska Föreningens i Stockholm Förhandlingar, v. 104, p. 369. 